\title{
Paleotectonic and paleogeographic history of the Arctic region
}

\author{
RON BLAKEY \\ Colorado Plateau Geosystems, 12222 N Paradise Village Pkwy, unit 110, Phoenix, Arizona 85032 USA \\ rblakey@deeptimemaps.com
}

Date received: 28 October 2019 g Date accepted: 21 May 2020

\begin{abstract}
Paleogeographic maps represent the ultimate synthesis of complex and extensive geologic data and express pictorially the hypothetical landscape of some region during a given time-slice of deep geologic time. Such maps, presented as paired paleogeographic and paleotectonic reconstructions, have been developed to portray the geologic history of the greater Arctic region over the past 400 million years. Collectively they depict four major episodes in the development of the Arctic region. The first episode witnessed early and middle Paleozoic terrane assembly and accretion during the Caledonian and Ellesmerian orogenies, which brought together many pieces of the Arctic collage along the northern margin of Laurussia. During the second phase, the assembly of Pangea in the late Paleozoic joined Siberia to Laurussia, an entity that became Laurasia during the subsequent break-up of Pangea. Then, Mesozoic subduction and terrane accretion constructed the Cordilleran margin and opened the Canada Basin. Finally, Cenozoic North Atlantic sea-floor spreading fully opened the Arctic Ocean.
\end{abstract}

\section{RÉSUMÉ}

Les cartes paléogéographiques représentent la synthèse ultime de données géologiques complexes et variées; elles dépeignent en images le paysage hypothétique d'une certaine région durant un créneau temporel donné d'un temps géologique profond. Les cartes en question, présentées sous forme de reconstructions paléogéographiques et paléotectoniques jumelées, ont été créées pour représenter le passé géologique de la grande région de l’Arctique au cours des 400 derniers millions d’années. Elles illustrent collectivement quatre épisodes marquants du développement de la région de l'Arctique. Le premier épisode a été témoin de l'assemblage et de l'accrétion du terrane du Paléozoïque précoce et moyen durant les orogenèses calédonienne et ellesmérienne, qui ont réuni de nombreux éléments de la mosaïque de l'Arctique le long de la marge septentrionale de l'Euramérique. Durant la seconde phase, l'assemblage de la Pangée a réuni vers la fin du Paléozoïque la Sibérie à l'Euramérique, une entité qui devint la Laurasie au cours du démembrement subséquent de la Pangée. La subduction et l'accrétion du terrane au cours du Mésozoïque a ensuite créé la marge de la Cordillère et a ouvert le bassin Canada. L'expansion océanique de l'Atlantique Nord du Cénozoïque a finalement complètement ouvert l'océan Arctique.

[Traduit par la redaction]

\section{INTRODUCTION}

The greater Arctic region encompasses the Arctic Ocean and surrounding continental shelves and landmasses that together represent a diverse and tectonically complex arrangement of crustal elements that span and surround the North Pole (Fig. 1). These elements have been formed and assembled over hundreds of millions of years, mostly in regions far removed from the present North Pole, by processes of continental collision, terrane accretion, rifting, transform faulting, subduction, and volcanism (see Shephard et al. 2013, table 2; and Petrov et al. 2016, table 1, for comprehensive lists of these elements). The description, including basic geologic data, origin, and geologic history and significance of many of these elements, is debated in the geologic litera- ture and remains a challenge to reconstructing the geologic history of the Arctic region as a whole. One key question revolves around the tectonic nature of the deeper parts of the Arctic Ocean: how much, if any, Precambrian and Paleozoic continental crust lies in the central basin (Miller et al. 2017; Petrov and Pubellier 2018; Smelror and Petrov 2018)?

Much previous work has focused on sub-regional studies or analyses of geology representing restricted time slices; disagreements between these focused studies have hindered comprehensive analysis of the geologic history of the region. However, several international pan-Arctic projects have overcome these challenges, resulting in series of Arctic geological and geophysical correlations and map compilations; they include maps of ocean bathymetry, bedrock geology, gravity anomaly, magnetic anomaly and tectonics (Petrov et 


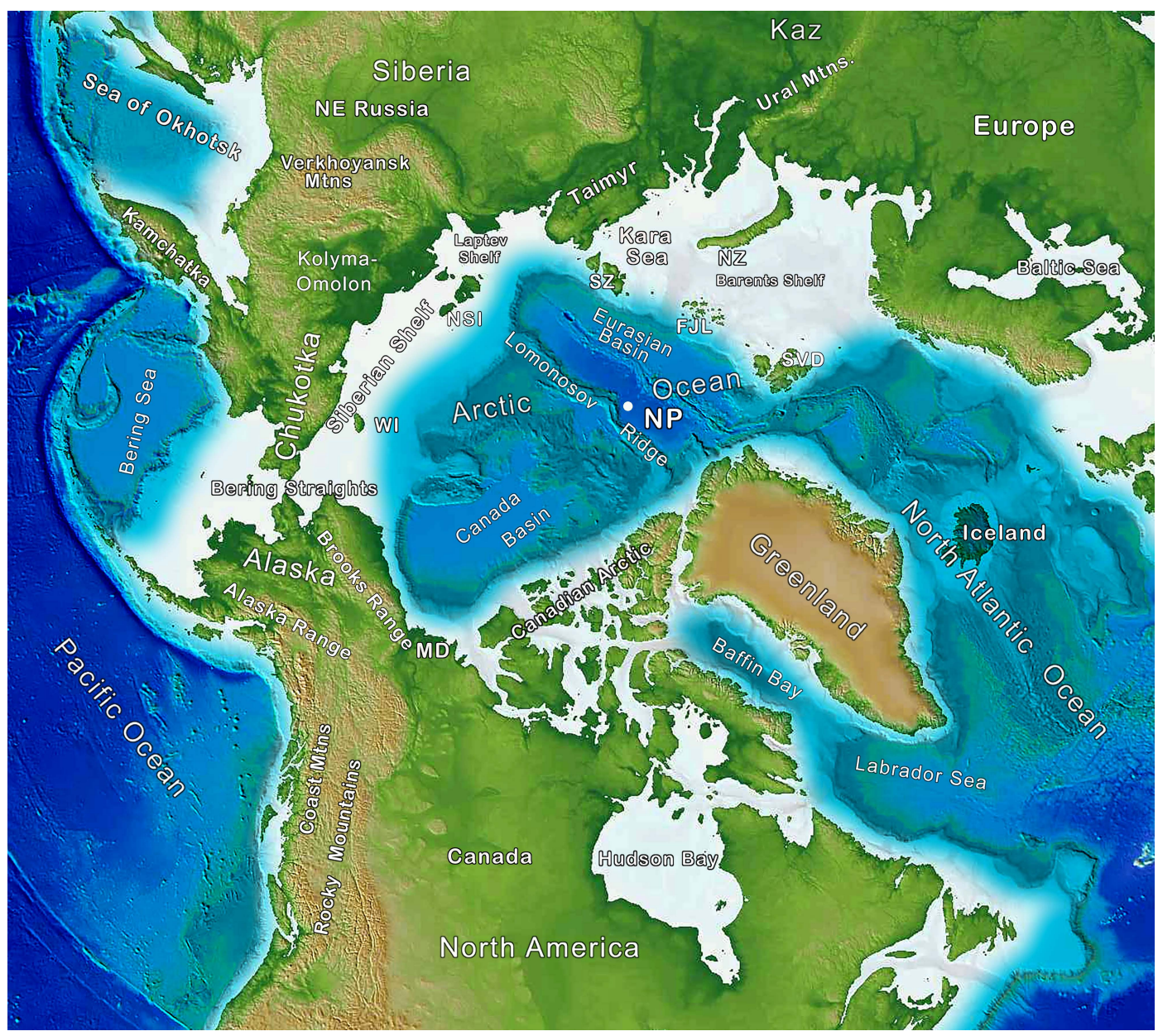

Figure 1. Topography of circum-Arctic region showing major oceanographic and continental features. FJL $=$ Franz Josef Land; KAZ = Kazakhstan; MD = Mackenzie Delta; Mtns = mountains; NP = North Pole; NSI = New Siberian Islands; NZ = Novaya Zemlya; SVD = Svalbard; SZ = Severnaya Zemlya; WI = Wrangell Island. DEM generated in GeoMapApp (see text).

al. 2008; Petrov et al. 2016; Petrov and Pubellier 2018). Embry et al. (2019) documented numerous sequence boundaries at about 10 myr intervals that permeate the stratigraphic record from $550 \mathrm{Ma}$ to the present. These authors interpret the sequence boundaries as tectonically induced features that mark uplift followed by subsidence and sedimentation. The ultimate significance of these surfaces is yet to be determined. Finally, late Neogene uplift and erosion and Quaternary glaciations have overprinted older geological settings. The remoteness and challenging climate of the Arctic have hindered detailed geologic investigations and, until the last 20 or so years, the circum-Arctic region was one of the leastknown regions on Earth in terms of its geology and geologic history.

In spite of these issues, there is general agreement that the geologic evolution of the Arctic region is punctuated by several large orogenic events, which include those in the Neoproterozoic Timanian orogen, the Silurian Caledonian orogen, the Devonian-Mississippian Ellesmerian orogen, the Permian-Triassic Ural-Taimyr orogen, and the Mesozoic-Cenozoic Cordilleran, Verkhoyansk and Eurekan orogens. These seminal events as well as those in several sub-regional orogens have shaped the greater Arctic region. Further modification by transform faulting, rifting, and sea-floor-spreading events have modified the region; and Quaternary glaciations have left a final mark on the presentday Arctic landscapes.

\section{NATURE, SCOPE, AND METHODOLOGY}

The purpose of this paper is to present a series of paleotectonic and paleogeographic maps that illustrate the geologic history of the greater Arctic region and facilitate discussion. Fifteen time slices from the Silurian to the present illustrate a continuous history of the region using data and models from the literature. Each time slice portrays continuity with adjacent time slices by respecting principles of plate tectonics and other geologic principles. For example, the successive maps obey the theoretical limits of plate motions and other long-term processes; however shorter-term processes such as transgression and regression cannot be shown because of the length of time between time slices. Each time slice presents a view averaged over several million 
years, and the shorelines represent maximum transgression over the interval of the given time slice. The range or "error bar" for each time slice is $\pm 3-5$ million years from the age given for the time slice. The 2020 timescale (Gradstein et al. in press) is used in this paper.

The interpretations presented here have been pieced together from the literature on the Arctic region, with most articles covering smaller areas or shorter spans of time than the maps. The plate-tectonic setting of the Arctic region has been presented in several recent papers for the Paleozoic (Domeier and Torsvik 2014; Vernikovsky et al. 2013), Mesozoic and Cenozoic (Seton et al. 2012; Shephard et al. 2013) and broader Phanerozoic (Paleozoic-Mesozoic; Colpron et al. 2007; Metelkin et al. 2015; Miller et al. 2017); the general plate geometry of these studies is followed here. Other recent, focused studies, provided additional data used in the construction of the present maps (see references in text and figure captions). Numerous aspects of Arctic geology remain unresolved or controversial, especially the Mesozoic history of the opening of the Amerasia Basin. In contrast, the opening of the Eurasia Basin and the evolution of features related to it are more clearly understood (Smelror and Petrov 2018). The succession of events shown on the present maps resulted from a compromise of interpretations presented in previous studies. This raises an important concept - the individual paleogeographic maps show how the region might have appeared, rather than how it did appear.

Map construction followed a regimented process to achieve continuity and accuracy for the 420 million-year span represented by the 14 time slices. The plates were mapped in rectangular projection following the Paleozoic patterns of Domeier and Torsvik (2014) and the MesozoicCenozoic patterns of Seton et al. (2012). Orthographic views were constructed from the rectangular projections in which Laurentia-North America was held fixed at the base of the map view. (Note that the term Laurentia is used to refer to the late Proterozoic craton that forms the bulk of the present North American continent; I use the term Laurentia until Cretaceous time). The centre point for each orthographic projection, which is not the same as the centre of the map, is listed in the respective figure caption; note that Silurian and Devonian projections are centred on the equator and subsequent time slices migrate northward, so that from 110 Ma to present, the centre of projection is the North Pole. Map edges, size (area covered), and scale remain the same for each map. Modern shorelines and large lakes are shown for orientation. The total map area was chosen so that all major regions associated with the evolution of the Arctic region are included. Orthographic projections have very little distortion, either with area or distance and direction, within approximately $30^{\circ}$ of the centre of projection, but distortion progresses logarithmically outwards of this line. Therefore, the corners of each map display the greatest distortion.

After the maps were consistently oriented with North America fixed (note consistent location on each map of the distinctive modern outline of Hudson Bay) and major tectonic and topographic features were located using the current geologic literature. The maps were checked for consistency, accuracy, and continuity throughout the 420 million years. The maps were "painted" in Photoshop ${ }^{\circledR}$ - water depth increases with darker blue so that the area of greatest contrast clearly shows the edges of the continents, arcs, ridges, and other shallower features. Land features were cloned using GeoMapApp 3.6.6 (http://www.geomapapp. org) with GRMT Image Version 3.5 and Blue Marble Next Generation overlay (Ryan et al. 2009). Modern topographic elements were used to portray ancient elements presumed to be analogous with the modern feature. Considerable editing such as resizing, recolouring, and reshaping was performed to blend elements into the maps (Fig. 2). Maps were further shaded to imply vegetation and climate. All features shown on the map should be considered qualitative rather than quantitative.

\section{GEOLOGIC HISTORY}

\section{Pre-Silurian}

Prior to the Silurian, the elements that now constitute the Arctic region were widely scattered across the globe (Fig. 3), and numerous hypotheses exist concerning their origin and distribution (Nokleberg et al. 2000; Miller et al. 2010; Nelson et al. 2013; Smelror and Petrov 2018). The major continents, Laurentia, Baltica and Siberia, were separated by large early Paleozoic oceans, Iapetus, Ural, and Ran (Domeier 2015; Torsvik and Cocks 2017). Numerous smaller terranes, now within the Arctic region and referred to as circum-Arctic terranes, were part of an accretionary orogenic belt that had a complex Paleozoic to Triassic history coeval with the assembly of Pangea; these terranes have been treated either as loosely assembled to independent blocks that accreted during various middle Paleozoic to Triassic orogenies (Colpron and Nelson 2009, 2011; Miller et al. 2011), or as a coherent microcontinent ("Arctida") that accreted to Laurentia in the Silurian to Devonian and has been subsequently dismembered and reshaped by late Paleozoic, Mesozoic and Cenozoic tectonics (Kuznetsov et al. 2010; Vernikovsky and Dobretsov 2015). Table 1 lists these terranes and provides a brief summary of their geologic history; many of these terranes and related elements are described in more detail in Colpron and Nelson $(2009,2011)$ and Shephard et al. (2013).

\section{Silurian}

The Late Ordovician-Silurian Caledonian orogen was the locus of collisions between Baltica, Laurentia, and Avalonia that terminated the Iapetus Ocean and created Laurussia, also known as Euramerica and "the Old Red Continent" (Friend and Williams 2000; McKerrow et al. 2000; Gasser 2013). Baltica and Laurentia collided directly with minor transform component to generate a substantial mountain 

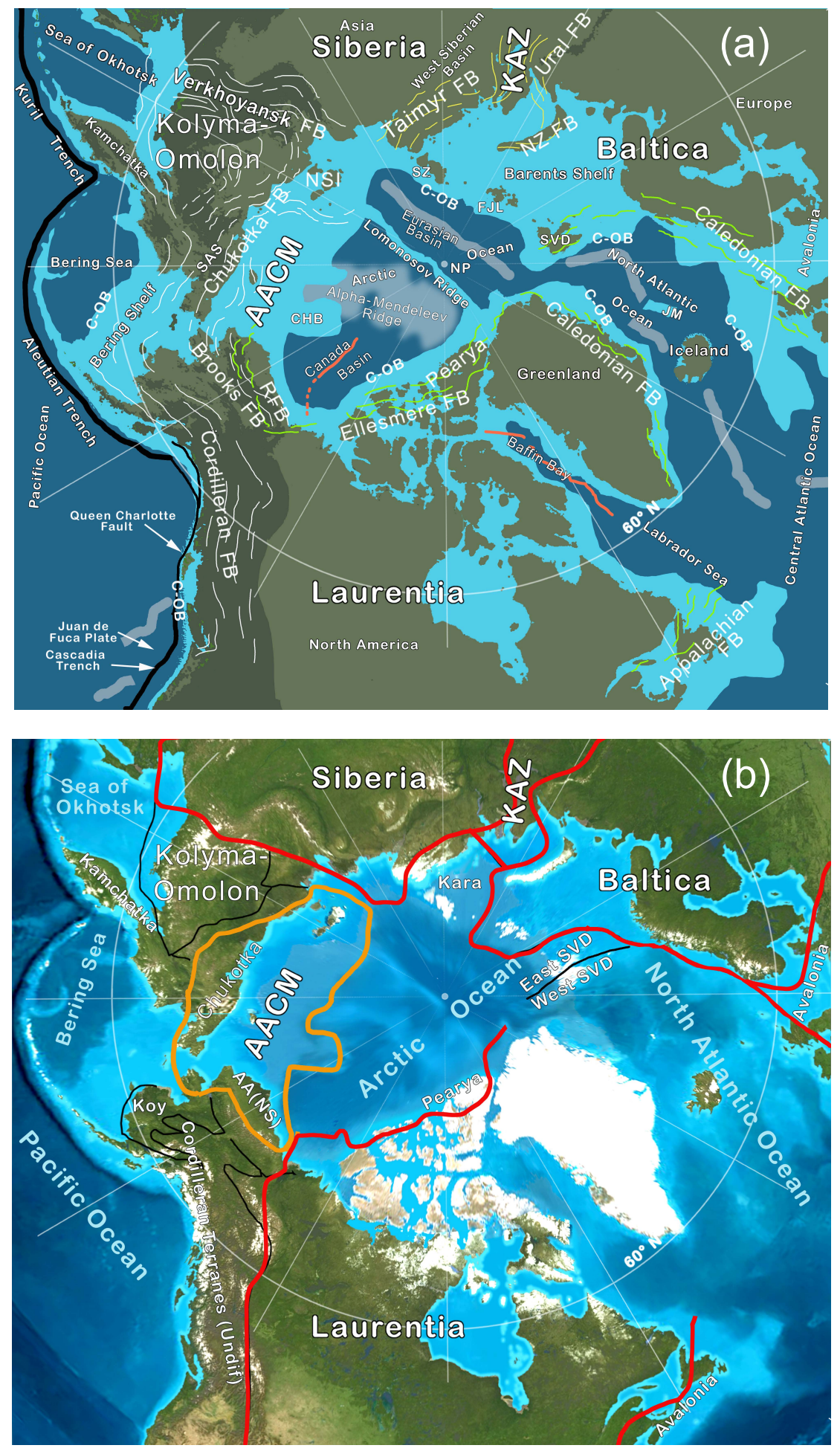

Figure 2. (a) Simplified tectonic map of circum-Arctic region. Deep blue = ocean basin (abyssal); pale blue = continental shelf, extended continental crust, and island arcs; grey heavy lines = mid-ocean ridges; grey area under "Alpha-Mendleev Ridge" = Early Cretaceous large igneous province; thin orange line = extinct mid-ocean ridges; light green wavy lines = Silurian-Mississippian fold belts; yellow wavy lines = Permian-Triassic fold belts; white wavy lines = Mesozoic-Cenozoic fold belts; olive green $=$ land; dark green $=$ mountains. See Figure 1 and Table 1 for list of abbreviations. (b) Present tectonic components that comprise the Arctic region. Precambrian cratons outlined in red; Arctic Alaska-Chukotka Microcontinent $(\mathrm{AACM})$ outlined in orange. Other terranes and blocks outlined in black. KAZ = Kazakhstan; KOY = Koyukuk and related arc and oceanic terranes; AA(NS) = Arctic Alaska (North Slope); SVD = Svalbard. Base map generated in GeoMap-App with Blue Marble overlay. Avalonia is a composite terrane accreted to Baltica and Laurentia in the Silurian and Devonian. 


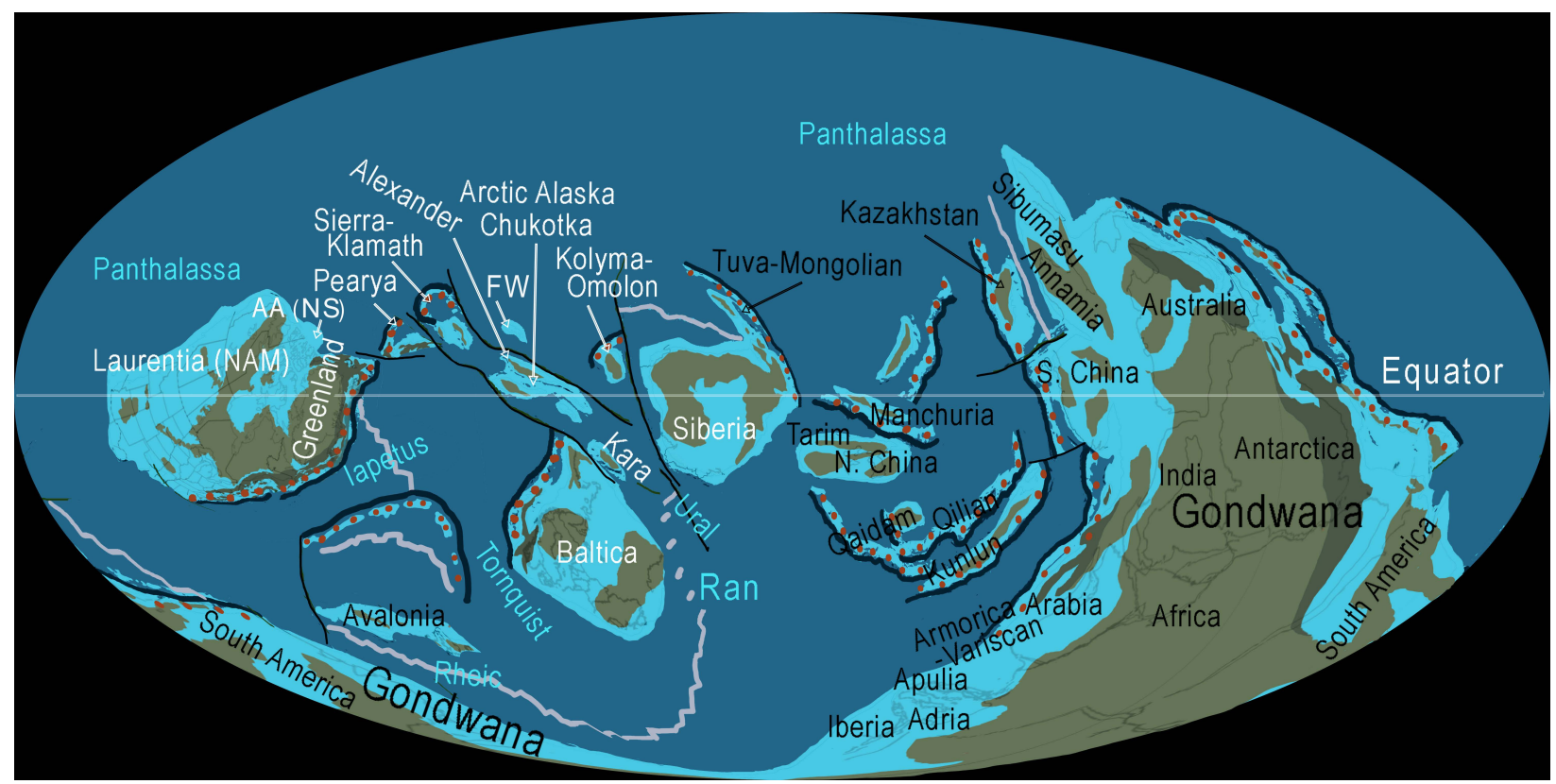

Figure 3. Late Ordovician (ca. $450 \mathrm{Ma}$ ) global paleogeography and paleotectonics, Mollweide projection. Components of circum-Arctic region labeled in white; colour scheme on this and subsequent tectonic maps same as used in Fig. 2 a. Major plate locations after Torsvik and Cocks (2017); shorelines from many sources.

range that sutured the two continents into a joined landmass that lay astride the equator (Torsvik and Cocks 2017). The north and east margins of the new continent constituted an active plate boundary with the Panthalassa Ocean, and a series of arcs and microcontinents lay adjacent to or outboard of this margin (Fig. 4). Although several models depict the tectonic setting and geometry of this margin (Beranek et al. 2015), the configuration of Colpron and Nelson (2011) and Nelson et al. (2013) are followed on Figure 4; in that version, several terranes are loosely arranged behind one or more arc systems that migrated obliquely along the Canadian Arctic. Pearya was the first terrane to accrete, probably during the early or middle Silurian (Anfinson et al. 2012; Beranek et al. 2013) as an extension of the Caledonian orogen (Trettin 1987; Colpron and Nelson 2011; Miller et al. 2017). Following the accretion of Pearya, outboard terranes collided obliquely farther west (present coordinates), probably as an irregular ribbon-shaped or boudin-like chain of microcontinents that trailed behind one or more arc systems (Fig. 4). Ordovician arc rocks in eastern Alaska (see below) may have been derived from these arc systems (Strauss et al. 2018a). Colpron and Nelson (2011) speculated that part of this arc system (SKT on Fig. 4) circumvented the northwestern promontory of Laurentia and then migrated southward along the Cordilleran margin and are now preserved as exotic terranes in the Klamath and northern Sierra Nevada Mountains of California. At the same time, another element, Alexander, rifted and drifted westward into Panthalassa. Other terranes believed to have been part of the collage include Kara, Franz Josef Land, and the Arctic Alaska-Chukotka Microcontinent (AACM) as well as several smaller terranes and arc-oceanic material. The pattern of tectonic elements shown on Figure
4 is based on hypotheses presented by Colpron and Nelson (2011), who provided a thorough description of the nature and history of these elements. Variations of this model postulate that Kara and Franz Josef Land were attached to form an extended promontory to northern Baltica (Torsvik and Cocks 2017); or that all of these elements were blocks within the "Arctida" continent (Kutnetsov et al. 2010). Regardless of the details concerning the geometry of these terranes, consensus suggests that many or most of the elements of the present circum-Arctic region (except for Siberia which was off the northeastern corner of the map) were in the vicinity of the Canadian Arctic Islands and northern Baltica by the middle Silurian.

Silurian sedimentary rocks are widespread across the circum-Arctic region and support the tectonic relations presented above. In the early to middle Silurian, northern and eastern Baltica was occupied by a broad carbonate platform that stretched from Novaya Zemlya to the Black Sea region (Nikishin et al. 1996; Cocks and Torsvik 2005) on a passive margin. An irregular epicontinental and pericontinental carbonate sea covered parts of north-central and western Laurentia, and Silurian carbonates are preserved on AACM, Kara, Franz Josef Land, Farewell and Alexander (Cook and Bally 1975; Torsvik and Cocks 2017). These carbonates are characterized by Uralian-Baltican sponges (Soja and White 2016) and reefs and warm-water faunas that indicate a tropical setting (Torsvik and Cocks 2017). Late Silurian deposits in the Canadian Arctic mark the approach and docking of Pearya. Prior to the arrival of Pearya, the Canadian Arctic Islands were part of a Neoproterozoic to Ordovician passive margin that ranged from shallow shelf to the southeast to deep shelf to continental slope and rise to the northwest; 
Table 1. Terrane origin and history.

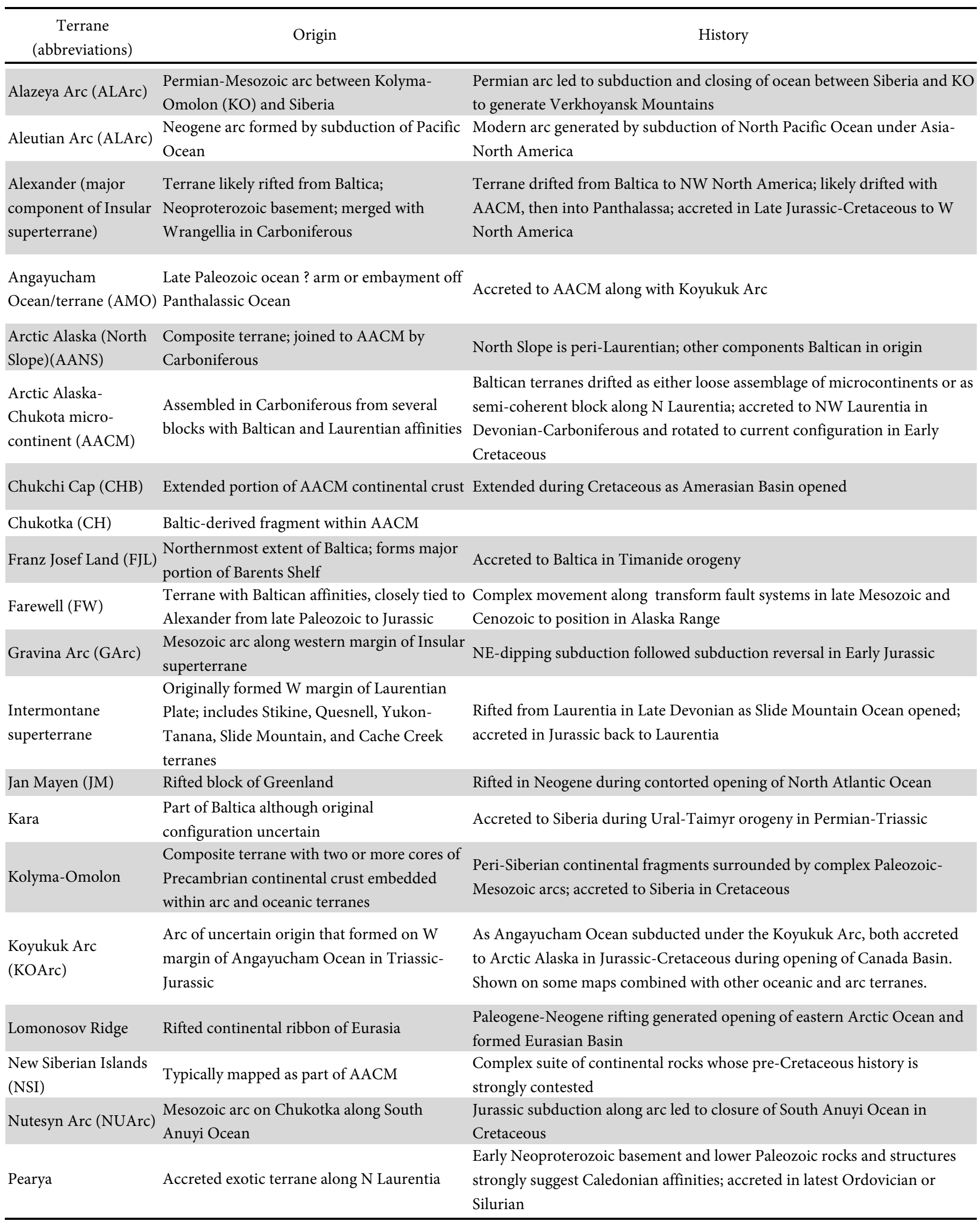


Table 1. Continued.

\begin{tabular}{|c|c|c|}
\hline $\begin{array}{c}\text { Terrane } \\
\text { (abbreviations) }\end{array}$ & Origin & History \\
\hline $\begin{array}{l}\text { South Anuyi } \\
\text { Ocean/suture (SAO; } \\
\text { SAS) }\end{array}$ & $\begin{array}{l}\text { Paleozoic-Mesozoic embayment of } \\
\text { Panthalassic Ocean - likely continuous with } \\
\text { Angayucham Ocean to S; suture separates } \\
\text { Kolyma-Omolon from Chukotka }\end{array}$ & $\begin{array}{l}\text { Triassic-Jurassic subduction along Alazeya Arc and Nutesyn Arc led to } \\
\text { closure with suturing in Cretaceous; suture zone likely transform fault }\end{array}$ \\
\hline $\begin{array}{l}\text { Talkeetna-Bonanza } \\
\text { Arc (TBArc) }\end{array}$ & $\begin{array}{l}\text { Triassic-Jurassic west-dipping subduction } \\
\text { under Wrangellia-Peninsular terranes }\end{array}$ & $\begin{array}{l}\text { Subduction waned in Jurassic and was replaced by east-dipping Gravina } \\
\text { Arc }\end{array}$ \\
\hline $\begin{array}{l}\text { Uda-Murgal Arc } \\
\text { (UMArc) }\end{array}$ & $\begin{array}{l}\text { Long-lived Paleozoic-Mesozoic arc along } \\
\text { Panthalassic margin of Kolyma-Omolon and } \\
\text { Siberia }\end{array}$ & Overprinted by younger arcs and events including accretion of Kamchatka \\
\hline
\end{tabular}

silicic sediment was derived from the Laurentian shield during the Neoproterozoic and Cambrian and is overlain by broad carbonate-shelf deposits (Anfinson et al. 2012). As Pearya approached, a foredeep developed between it and the passive margin into which the turbidites of the Danish River and Fire Bay formations were deposited (Dewing et al. 2019). The turbidites were thrust over the passive margin and deformed as Pearya docked during the middle Silurian (about 425 Ma; Trettin et al. 1991). By Early Devonian, deep-water deposits were succeeded by fluvial and shallow marine molasse deposits (Beranek et al. 2013). The same history happened along the Norwegian-Greenland margins within the Caledonian fold belt, stretching from Britain to Svalbard and North Greenland; there, older Paleozoic marine platform sediments and subsequent thrust sheets were overlain by upper Silurian-Devonian continental deposits typical of the Old Red Continent (Smelror et al. 2009).

\section{Devonian}

By the Late Devonian, Laurussia was a massive continent with most circum-Arctic terranes firmly attached to its northern margin (Fig. 5). The northern Laurussian margin was composed of AACM, Kara, Franz Josef Land, Svalbard, Pearya, and associated arc terranes. The partly eroded Caledonian Mountains snaked from Scotland along the suture between Greenland and Baltica, and curved westward through Svalbard. As a general trend, orogenic activity youngs from southeast to northwest, beginning as early as $430 \mathrm{Ma}$ for the Scandian phase in the Caledonian orogen (Larsen and Bangaard 1991) to $390 \mathrm{Ma}$ for the Romanzof orogen (Lane 2007); thus circum-Arctic terranes closed zipper- or jaw-like on northern Laurentia. However, late folding of Franklinian basin strata of Ellesmere Island at $350 \mathrm{Ma}$ (Tournasian) greatly extends the age range of the
Ellesmerian orogeny (Embry 1991). Outboard of the Canadian Arctic Islands were the Ellesmere highlands that shed sediments southeastward towards the northern margin of Canada (Embry 1993; Anfinson et al. 2012; Gottlieb et al. 2014). This area was a significant sediment source in the Late Devonian, in the Mississippian, (Anfinson et al. 2012) and again during the Permian (Alonso-Torres et al. 2018).

The history of assembly and docking of the terranes that now comprise AACM has recently been described in two different models. Miller et al. (2017) interpreted the Romanzof orogeny as the westernmost extension of the Caledonian orogeny and assigned the event an Early to Middle Devonian age; by Middle Devonian the AACM was assembled and in place along the western Canadian Arctic where its western margin was penetrated by late syn- and post-orogenic plutons ranging in age from 390 to $340 \mathrm{Ma}$. Miller $e t$ al. (2017) considered these events to be related to Devonian plate reorganization. In contrast, others (Strauss et al. 2018a, b; Colpron et al. 2018; Nelson et al. 2018) propose a more protracted orogenic history in which the Romanzof orogeny is interpreted as an Early to Middle Devonian event, probably representing the assembly of the peri-Laurentian North Slope subterrane with other elements of AACM. The final assembly of AACM was not complete until Early Mississippian, when the final docking of AACM occurred in the Canadian Arctic. This last event may have been responsible for the enigmatic Ellesmerian orogeny (Strauss et al. 2018a, b).

The model followed in Figures 4-6 follows the Northwest Passage hypothesis (Colpron and Nelson 2009, 2011; Nelson et al. 2013; Colpron et al. 2018; Nelson et al. 2018). The following concepts have evolved over the dozen or so years since the hypothesis was first conceived.

1. The terranes implicated have varying paleogeographic origins; the North Slope subterrane has Laurentian 

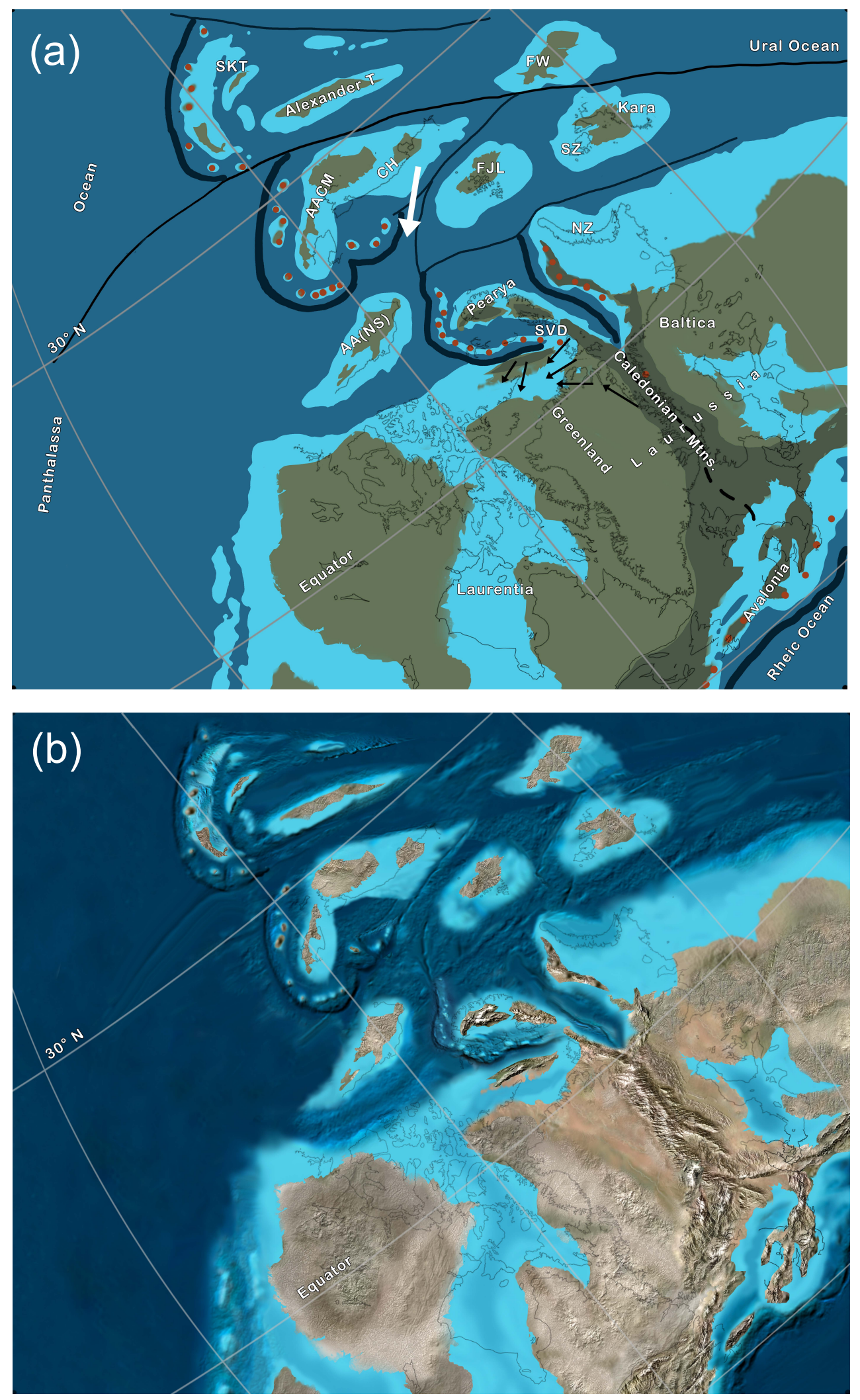

Figure 4. Late Silurian (ca. $420 \mathrm{Ma}$ ) paleotectonics and paleogeography showing initial docking of circum-Arctic terranes. See text for data sources for the maps. Centre of orthographic projection $0^{\circ} \mathrm{N} / \mathrm{S}, 120^{\circ} \mathrm{W}$ (graticule of Torsvik and Cocks 2017). (a) Paleotectonic map; see Table 1 for abbreviations and Figure 2a for key to colours and patterns on this and all subsequent maps. Additional patterns: white arrow: relative movement of circum-Arctic terranes to Laurentia; black dashed line $=$ Late Ordovician and early Silurian sutures; black arrows = sediment transport directions. (b) Hypothetical paleogeography; see text for description of features and discussion. 

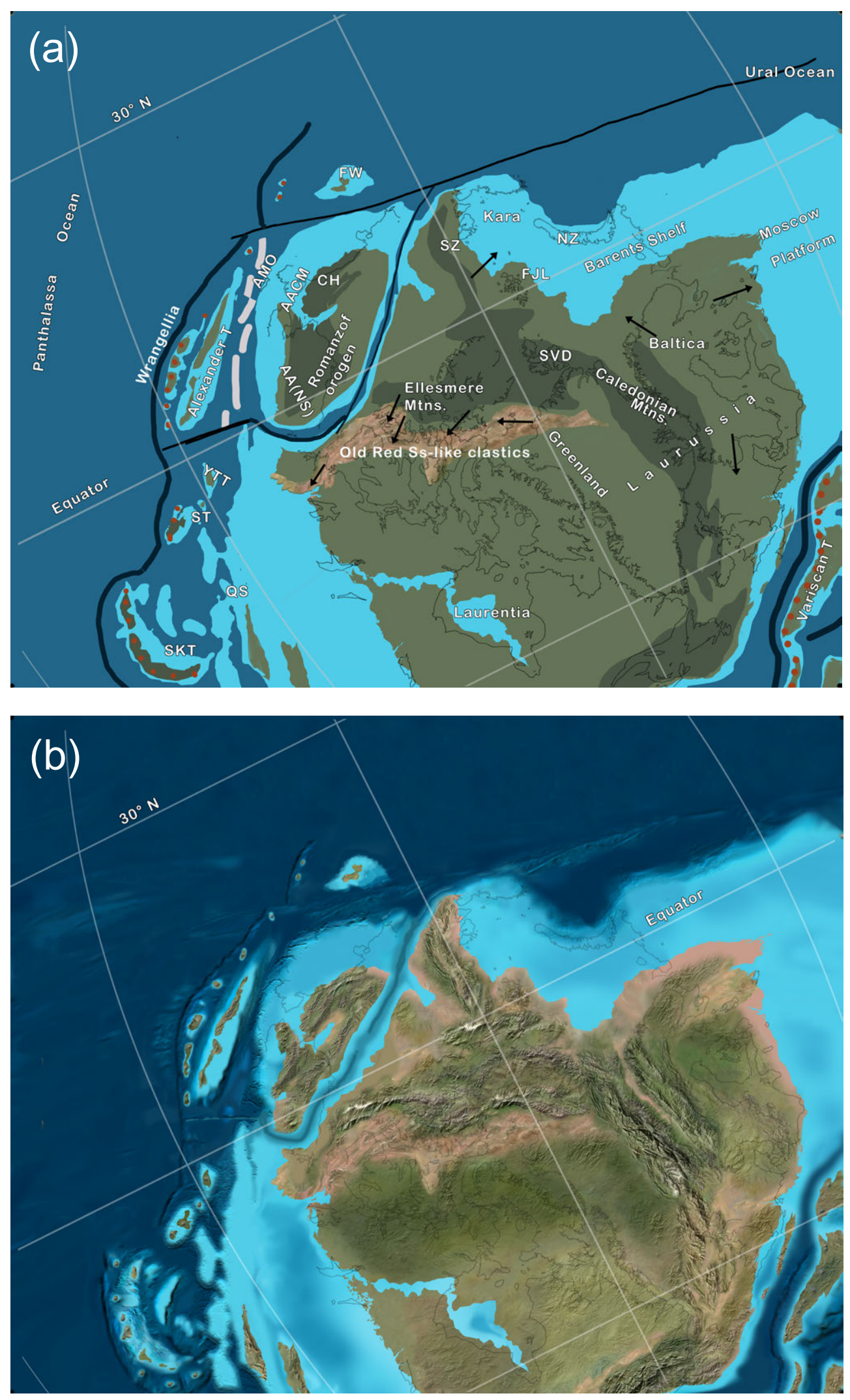

Figure 5. Late Devonian (ca. $380 \mathrm{Ma}$ ) paleotectonics and paleogeography showing early assembly of circum-Arctic terranes. See text for data sources for the maps. Centre of orthographic projection $0^{\circ} \mathrm{N} / \mathrm{S}, 90^{\circ} \mathrm{W}$ (graticule of Torsvik and Cocks 2017). (a) Paleotectonic map; black arrows = sediment transport directions. (b) Hypothetical paleogeography; see text for description of features and discussion. Pale orange/tan shows areas of predominantly fluvial Old Red Sandstone and equivalents. 
affinities, probably originating off Greenland or the Canadian Arctic (Fig. 4), whereas most other terranes have Baltic affinities (Nelson et al. 2013; Colpron et al. 2018; Nelson et al. 2018; Strauss et al. 2018a, b).

2. The final assembly of AACM was promoted by deformation in the Devonian-Carboniferous Romanzof and Ellesmerian orogenies (Figs. 5, 6), the understanding of which remains unclear (Straus et al. 2013).

3. The Alexander and Farewell terranes have close affinities with AACM and the three were likely in close paleogeographic position during Silurian and Devonian. During Devonian-Mississippian back-arc development associated with the opening of the Slide Mountain ocean (Monger and Nokleberg 1996), the Alexander and Farewell terranes - along with the Stikine, YukonTanana, and Quesnell terranes - formed a ribbon terrane (Fig. 6) that migrated westward into Panthalassa (Malkowski and Hampton 2014; Dumoulin et al. 2018a, b). The Paleozoic arcs of Wrangellia were initially built on Alexander, and the later Pennsylvanian "stitching" plutons were actually intruded into terranes that were already joined together (Israel et al. 2014).

4. Throughout the Devonian and Early Mississippian, parts of the arc system remained outboard of northwestern Laurentia and expanded southward and parallel to the western margin as a fast-moving Caribbean-like plate (Fig. 5, as SKT) that recorded tectonism along its path from Alaska to its current location in the Klamaths and Northern Sierra Nevada of California (Colpron and Nelson 2009, 2011; Nelson et al. 2013).

Devonian sedimentary rocks occur throughout the circum-Arctic region and in many places show a sharp increase in silicic sediment in contrast to the underlying Silurian rocks, which are mostly carbonates (Nikishin et al. 1996; Anfinson et al. 2012). Fluvial systems that drained the numerous Devonian mountains and uplands deposited reddish sandstone, conglomerate, and mudstone, historically collected under the term "Old Red Sandstone", and equivalent rocks (hence the alternative name Old Red Continent for Laurussia). The Old Red facies was deposited in a series of basins of various origins over much of Laurussia, including the Canadian Arctic and Arctic Alaska (Friend and Williams 2000; Nilsen 1981; Nilsen and Moore 1984). Detailed studies in Arctic Alaska and the Canadian Arctic record the sedimentary response to widespread tectonism: Anfinson et al. (2012) documented changing source areas for Devonian molasse deposits, and Gottlieb et al. (2014) demonstrated sediment response to continentward propagation of the Ellesmerian orogeny and sedimentary trends during and following the Romanzof orogeny, including uplift and cannibalization of older sedimentary rocks. Away from orogenic activity, Devonian marine sediments were widely deposited on continental shelves (Ziegler 1988; Nikishin et al. 1996; Lane 2007). Areas buffered from terrigenous input were dominated by carbonates, whereas sand and mud predominated in areas affected by silicic input.

\section{Early Carboniferous (Mississippian)}

Tectonism waned in the early Carboniferous (Mississippian), although thrusting in the Ellesmere Mountains continued into the Tournasian (350 Ma), and other parts of the Caledonian-Ellesmerian-Romanzof orogen underwent extension, including into the Caledonian Mountains (Larsen and Bangaard 1991) and Arctic Alaska (Gottlieb et al. 2014). The circum-Arctic terranes of Laurentia were nestled along the northern Laurussia margin while the Ural Ocean lay to the north (Fig. 6). As the Ural Ocean narrowed during the Early and Middle Mississippian, the Siberian continent and peri-Siberian terranes approached Laurussia along a transform and subduction margin that was strongly oblique (Domeier and Torsvik 2014).

Following the southward migration of terranes now in northern California along the western Laurentian margin, slab rollback and subsequent back-arc spreading in the Late Devonian and Mississippian opened the Slide Mountain and Angayucham oceans and rifted peri-Laurentian terranes westward into Panthalassa (Colpron and Nelson 2011). The northwestern Laurentian margin would remain passive until the Triassic and both Arctic Alaska and Chukotka contain upper Paleozoic shelf and passive margin successions that overlie deformed Devonian and older rocks (Gottlieb et al. 2014; Amato et al. 2015).

Carboniferous rocks overlie those deformed in the Caledonian-Ellesmerian-Romanzof orogeny across much of the Laurentian portion of the circum-Arctic region and document the contrast in tectonic setting of the Carboniferous and Permian with the older Paleozoic. In the embryonic Sverdrup Basin, Mississippian mudstones and conglomerates of the Emma Fiord and Borup Fiord formations overlie deformed Devonian and older rocks in evolving rift settings (Embry and Beauchamp 2008); and on the North Slope of Alaska, similar relations were documented by Gottlieb et al. (2014). Sources for both areas included Arctic Alaska and related terranes and sedimentary rocks of the inverted Ellesmere foreland basin. Across the Baltic margin of Laurussia, clastic sediment was shed into the Barents Shelf and onto Moscow Platform from highland sources to the west; these deposits graded eastward and northward into marine clastics and carbonates and included local evaporite deposits (Ziegler 1988). The Arctic Siberian margin has a lower and middle Paleozoic platform and passive margin sequence of marine rocks through the Mississippian (Torsvik and Cocks 2017).

\section{Late Carboniferous (Pennsylvanian)}

Middle and Late Mississippian tectonic trends continued into the Pennsylvanian (Fig. 7). As the Ural Ocean closed and Siberia transformed with left-lateral motion along the 

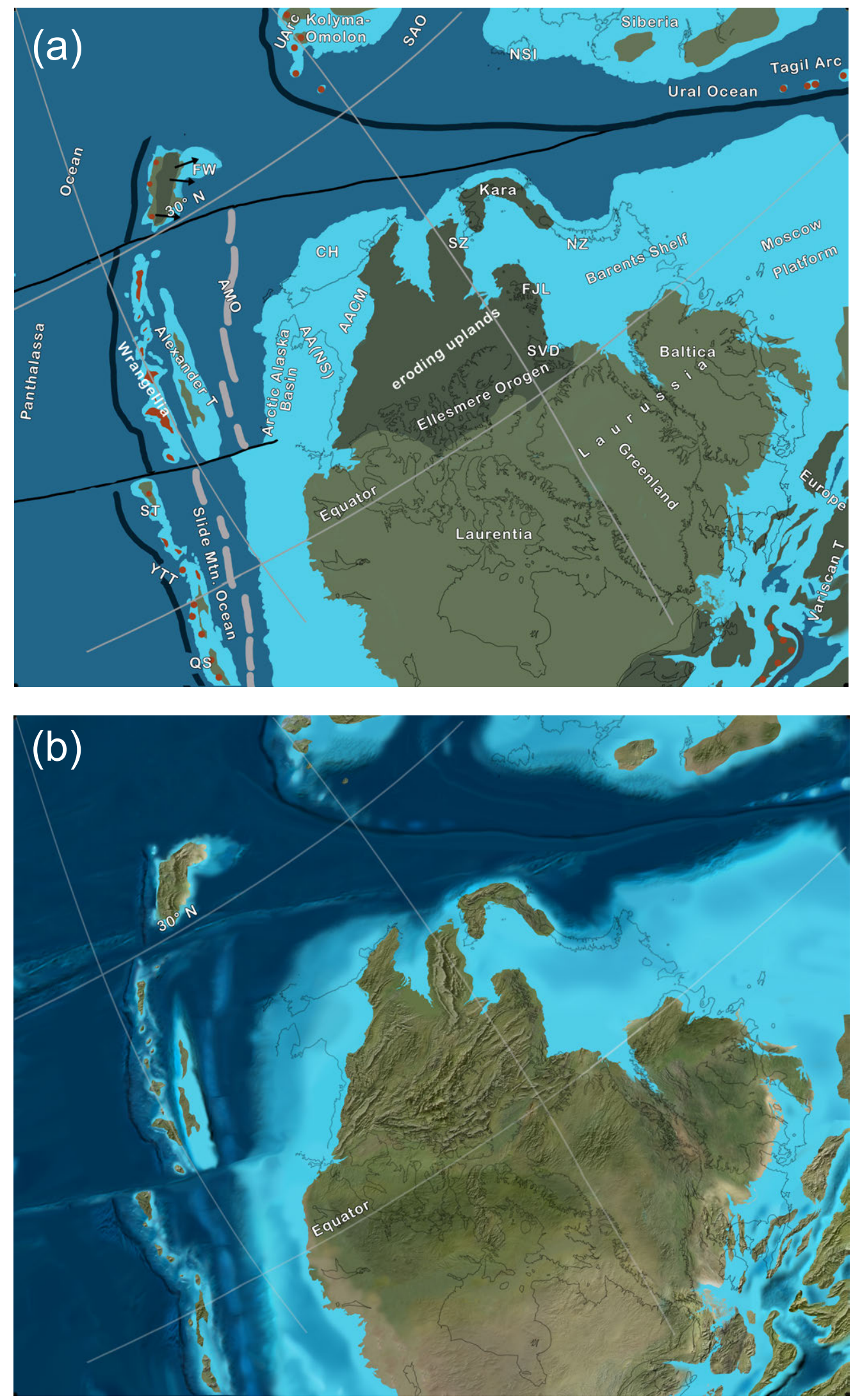

Figure 6. Early Mississippian (ca. $350 \mathrm{Ma}$ ) paleotectonics and paleogeography showing approach of Siberian continent towards Laurussian circum-Arctic terranes. See text for data sources for the maps. Centre of orthographic projection $10^{\circ} \mathrm{N}, 70^{\circ} \mathrm{W}$ (graticule of Torsvik and Cocks 2017). (a) Paleotectonic map. (b) Hypothetical paleogeography; see text for description of features and discussion. 

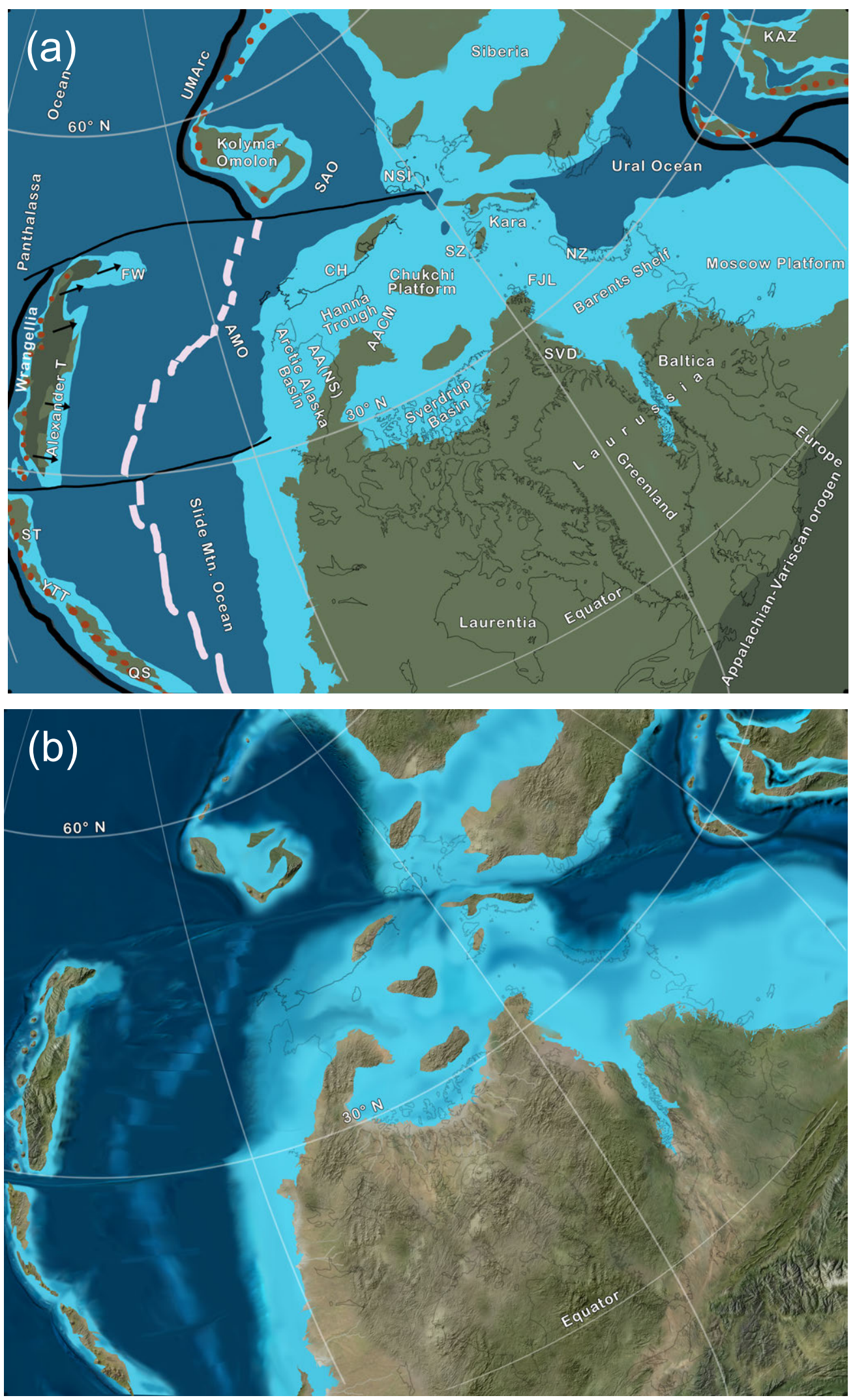

Figure 7. Early Pennsylvanian (ca. $320 \mathrm{Ma}$ ) paleotectonics and paleogeography showing initial interaction between Laurussia and Siberia. See text for data sources for the maps. Centre of orthographic projection $15^{\circ} \mathrm{N}, 30^{\circ} \mathrm{W}$ (graticule of Torsvik and Cocks 2017). (a) Paleotectonic map. (b) Hypothetical paleogeography; see text for description of features and discussion. The arcs and terranes west of the Slide Mountain Ocean may have been farther west off of the field of view on the map. 
northern margin of Laurussia, and Kazakhstan wedged between Siberia and Baltica, the supercontinent Pangea was assembled and motion between Laurussia and Siberia ceased (Domeier and Torsvik 2014). Those authors attributed sluggish motion between Laurussia and Siberia, including strong deformation in the Taimyr and Novaya Zemlya regions, to intra-plate deformation (see Permian and Triassic sections below). The Siberian elements of the circum-Arctic region included the Siberian craton and the Kolyma-Omolon superterrane (Torsvik and Cocks 2017). The ocean between these elements and Chukotka to the south is the South Anyui (or Anui) ocean, which apparently continued southward into the Angayucham and Slide Mountain Oceans (Fig. 7).

A broad inland sea separated Siberian elements from Laurussian elements, and Pennsylvanian marine sediments were deposited from the Moscow Platform, across the Barents Shelf, and into the Sverdrup Basin (Fig. 7). Carbonate and silicic sediment was deposited in this seaway and local thick evaporites accumulated in the Sverdrup Basin (Embry and Beauchamp 2008). A landmass that was an inverted foreland basin separated the Sverdrup Basin from the Arctic Alaska Basin and supplied sediment to each (Gottlieb et al. 2014). The Hanna Trough (Sherwood et al. 2002), another marine basin, looped to the north of the landmass and also received sediment from it; parts of the Chukchi platform and adjacent Arctic Alaska were emergent and also were sediment sources (Gottlieb et al. 2014). Large areas of Siberia, Baltica, and Laurentia were emergent through much of the Pennsylvanian (Torsvik and Cocks 2017).

\section{Permian}

The Permian and Triassic are difficult to model in the circum-Arctic region as the several recent versions show moderate to considerable variation. The problem is especially acute along the Panthalassa margin with Siberia and Laurentia, and with respect to the location, orientation, and presence of the numerous arcs that have been postulated (Parfenov et al. 1995; Nokleberg et al. 2000; Cocks and Torsvik 2011; Nelson et al. 2013; Shephard et al. 2013; Domeier and Torsvik 2014; Malkowski and Hampton 2014; Amato et al. 2015; Miller et al. 2017; Alonso-Torres et al. 2018).

The Permian represents an interval of plate reorganization in the eastern Panthalassic Ocean marked by subduction flip under the Yukon-Tanana and Quesnell terranes and back-arc closure of the Slide Mountain Ocean (Nelson et al. 2013). The geometry of subduction is complicated along western Laurentia by the final closure of the Slide Mountain Ocean in the Late Permian and the complex assembly of the Intermontane superterrane (Yukon-Tanana, Stikine, Cache Creek, Slide Mountain, and Quesnel terranes) during the Triassic and Early Jurassic. The tectonic sequences of these events are shown on Figures 8-10 and follow the models of Milhalynuk et al. (1994), Monger (2008), and Nelson et al. (2013). Further discussion of this model and the complexities of the Cache Creek Terrane are beyond the scope of this paper, so the interested reader is referred to the above works for additional explanation and detail.

The Permian-Triassic Uda-Murgal Arc, extended from and wrapped around the Kolyma-Omolon superterrane to Siberia and beyond (Seton et al. 2012; Shephard et al. 2013; Domeier and Torsvik 2014). Kolyma-Omolon lay off the Verkhoyansk margin of Siberia and was separated from AACM by the South Anyui Ocean (Fig. 8). The northern margin of Kolyma-Omolon was bordered by another arc that would eventually surround the terrane with subduction margins (Amato et al. 2015). A simpler model was proposed by Miller et al. (2017) in which subduction zones and associated arcs lay well offshore in Panthalassa, and the Amgayucham and Anyui oceans lay adjacent to the passive margin of Siberia and Laurentia.

The Ural orogeny marks the culmination of the assembly of Pangea, when Baltica, Kazakhstan, and Siberia collided and dramatically affected the margin of AACM; significant rifting developed across northern Siberia, in the west Siberian Basin, and between Norway and Greenland (Miller et al. 2017). Permian-Triassic deformation in Taimyr and Novaya Zemlya represents late intra-plate adjustment (Torsvik and Cocks 2017). Parts of AACM were positive and formed an important source of clastics for the Sverdrup Basin (AlonsoTorres et al. 2018).

Permian marine deposits dominated the shelves and basins adjacent to Baltica and Laurentia from the Moscow Platform to Arctic Alaska; northeastern Baltica, which was adjacent to the Ural Mountains, was blanketed in sand and gravel shed from the highlands (Ziegler 1988; Miller et al. 2017). In the late Paleozoic, rifting developed where the Caledonian Mountains once stood between Baltica and Laurentia, and the basin was filled with mixed clastic, carbonate, and evaporite deposits (Ziegler 1988). Rifting extended westward into the Sverdrup Basin where periods of rapid subsidence alternated with local uplift to produce a series of segmented basins and regional unconformities, with a general clastic increase upsection (Embry and Beauchamp 2008). The Sverdrup Basin apparently formed part of a continuous depocentre that extended westward across the Hanna Trough and into the Arctic Alaska Basin (Embry 1991; Gottlieb et al. 2014). The Permian deposits across the Arctic Alaska portion of AACM consist of shallow marine carbonates with interbedded mudstones (Miller et al. 2017).

\section{Triassic}

Significant intra-plate tectonics affected much of the circum-Arctic region as convergence took place along the Lomonosov Ridge and northwest to the New Siberian Islands, the Taimyr-Novaya Zemlya region, and along western Svalbard (Torsvik and Cocks 2017; Sauermilch et al. 2018). Diabase sills, coeval with convergence in the New Siberian Islands, suggest rifting (Miller et al. 2017). The Ural Mountains extended into Novaya Zemlya and Taimyr, and all three areas were important sediment sources during the Triassic (Petrov et al. 2008; Amato et al. 2015; Fleming et al. 2016). The Siberian traps, the largest continental large 

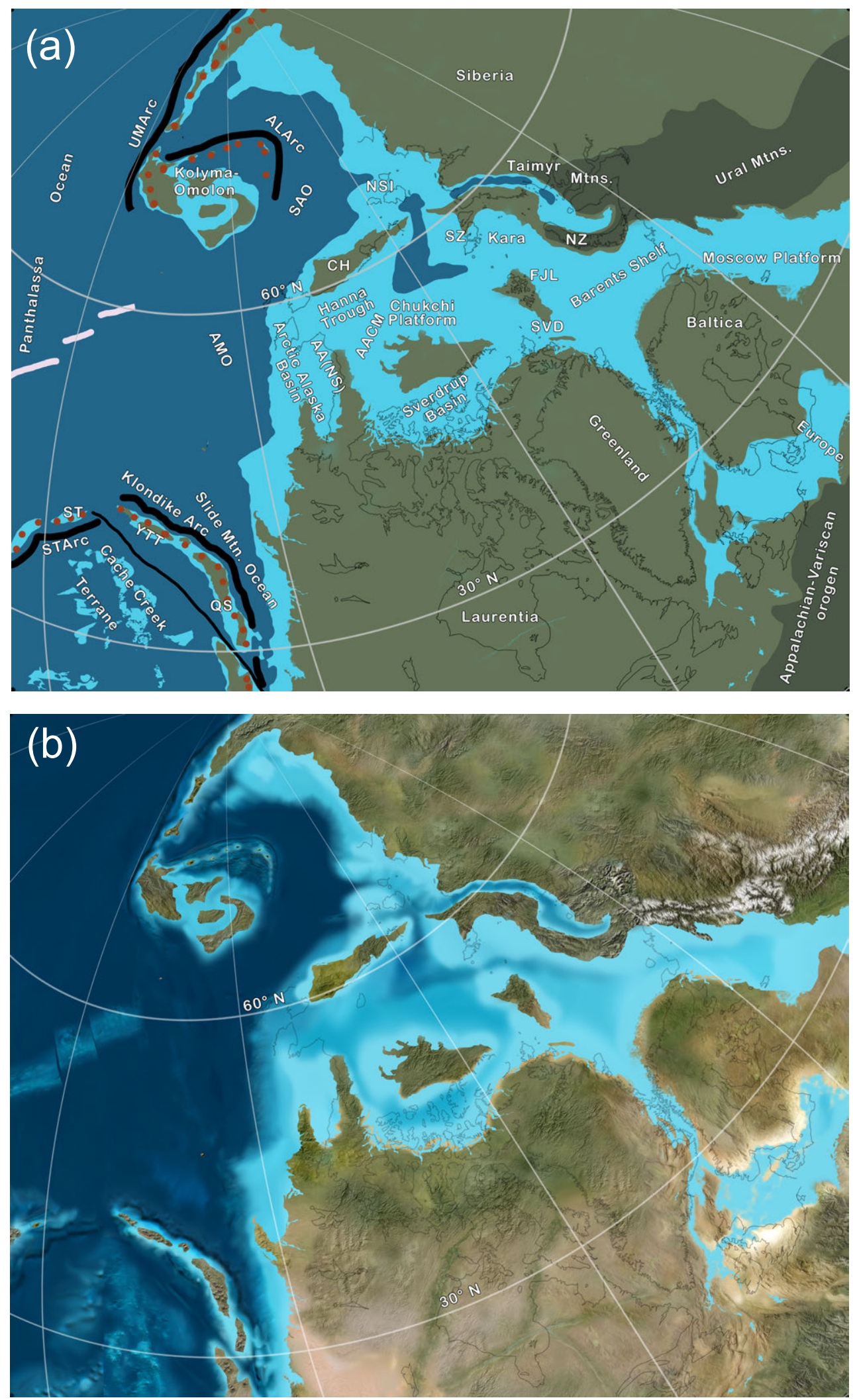

Figure 8. Middle Permian (ca. $260 \mathrm{Ma}$ ) paleotectonics and paleogeography showing the final assembly of Pangea across the circum-Arctic region. See text for data sources for the maps. Centre of orthographic projection $40^{\circ} \mathrm{N}, 10^{\circ} \mathrm{W}$ (graticule of Torsvik and Cocks 2017). (a) Paleotectonic map. (b) Hypothetical paleogeography; see text for description of features and discussion. Deepwater areas above Chukchi Platform and in Taimyr region may represent areas of thin or extended continental crust or small remnant ocean basins (Torsvik and Cocks 2017). Alexander and Farewell terranes were off the west edge of the map. 

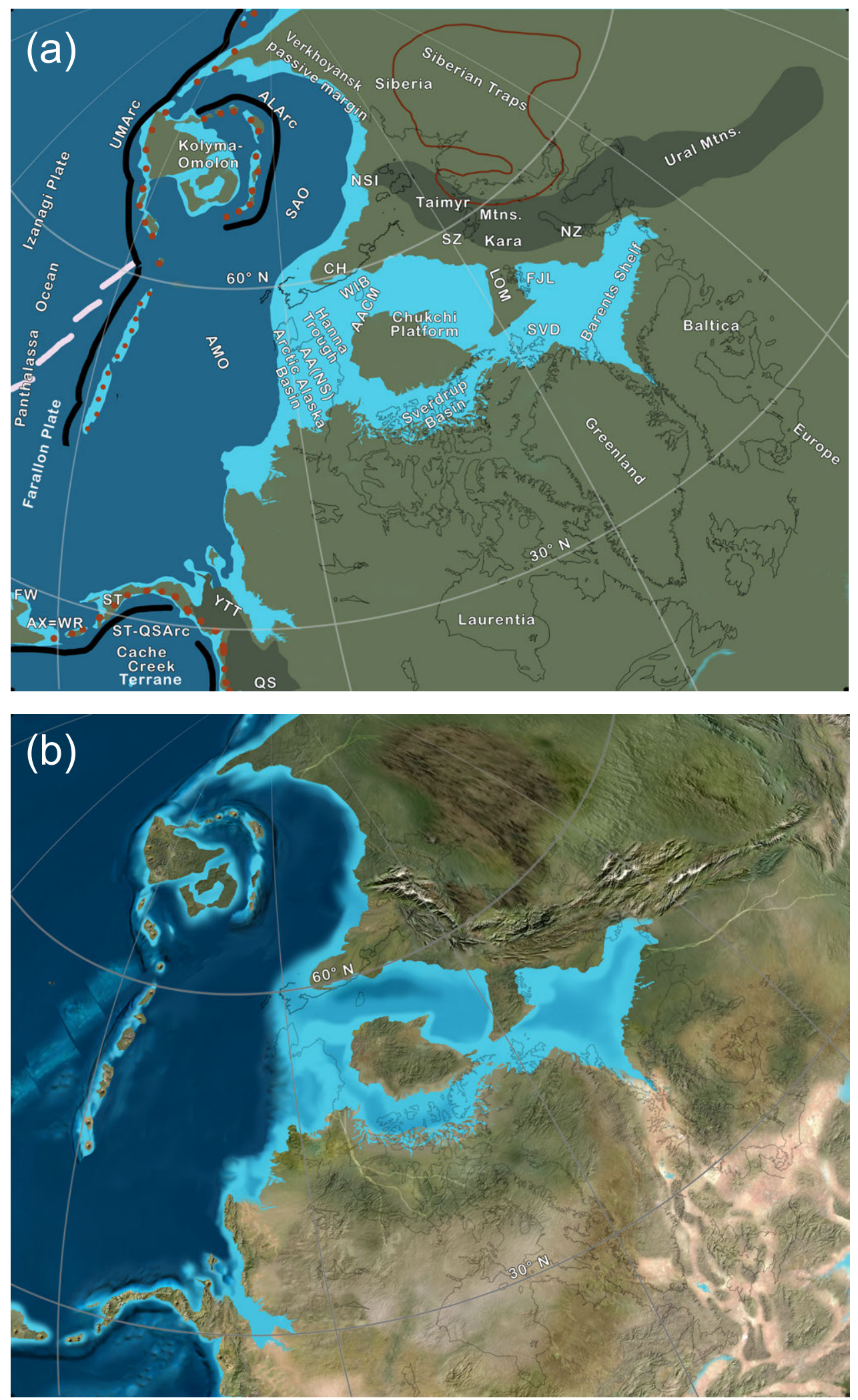

Figure 9. Middle Triassic (ca. $240 \mathrm{Ma}$ ) paleotectonics and paleogeography showing final closure of Ural and Taimyr Mountains; for the next 100 million years the circum-Arctic region will be enclosed within northwestern Pangea. See text for data sources for the maps. Centre of orthographic projection $50^{\circ} \mathrm{N}, 10^{\circ} \mathrm{W}$ (graticule of Seton et al. 2012). (a) Paleotectonic map; red outline marks extent of Siberian traps. (b) Hypothetical paleogeography; see text for description of features and discussion. Pale orange/tan areas show distribution of fluvial-eolian-lacustrine deposits; note the north-south rift pattern east of Greenland. 
igneous province, erupted at about $252 \mathrm{Ma}$ and extended into the Taimyrs; this igneous province was also an important sediment source area (Amato et al. 2015). Parts of AACM formed a large positive area that sourced the Sverdrup Basin and Hanna Trough (Alonso-Torres et al. 2018). Uplands in Baltica, Greenland, and Laurentia were local sediment sources (Ziegler 1988). Little or no sediment was derived from the offshore arc terranes in Panthalassa (Miller et al. 2017).

Following the closure of the Slide Mountain Ocean in the Late Permian, the western edge of Laurentia became an active, rapidly evolving margin that would dominate circum-Arctic tectonics during the Mesozoic. One or more offshore subduction zones stretched nearly the length of Laurentia while subduction continued northward along the Verkhoyansk region of Siberia (Fig. 9) towards the eastern margin of Asia (the subduction zone crossed the North Pole, so west and east directions are reversed) (Seton et al. 2012). Although tectonic events for this time in Panthalassa are poorly documented, the ocean crust was divided into three huge oceanic plates, the Izanagi Plate to the northwest, the Farallon Plate to the southeast, and the Phoenix Plate (not shown on Fig. 9) to the south and southwest (Seton et al. 2012; Shephard et al. 2013; Domeier and Torsvik 2014). However, during the Triassic and Early Jurassic, the Farallon Plate had not yet reached western Laurentia, at least not within the area under consideration, but lay to the west of the various offshore arcs. The South Anyui and Angayucham Oceans formed a broad back-arc region that separated the Kolyma-Omolon superterrane and the arc-subduction zone from the remainder of the circum-Arctic region (Fig. 9). The Alazeya-Oloy arc began prograding towards the Verkhoyansk passive margin (Amato et al. 2015).

In general, siliciclastics are the dominant Triassic sediment type across much of the circum-Arctic region (Ziegler 1988). Thick, deep-water turbidites were deposited along Chukotka and across Wrangel Island (Miller et al. 2010; 2017) and in the Sverdrup Basin (Embry and Beauchamp 2008). Triassic continental deposits with basal interbedded volcanic rocks (Miller et al. 2017) mark the earliest deposits in the West Siberian Basin, and marine sandstone and mudstone with interbedded evaporites were deposited in the elongate basin between Greenland and Baltica (Ziegler 1988). The Barents Sea region was the site of extensive fluvialdeltaic sedimentation (Figs. 9B and 10B), which Klausen et al. (2019) speculated constituted the largest delta plain in Earth's history. Huge river systems sourced interior Siberia and the Ural Mountains and deposited thick clastic wedges in Arctic Siberia (Miller et al. 2017). Most of these deposits formed in basins with origins generally attributed to widespread Permian-Triassic rifting across the region (Ziegler 1988; Embry and Beauchamp 2008; Miller et al. 2010; 2017).

\section{Jurassic}

The Jurassic was a time of significant change in the tectonic regime across the circum-Arctic region as Triassic offshore arcs began to encroach and then collide with northwestern Pangea (Figs. 10-11). At the Triassic/Jurassic transition most of the region was little changed from the Early Triassic, but by the Middle Jurassic, significant changes were evident following a major Early Jurassic marine transgression across most shelves in the region (Ziegler 1988). As the Panthalassa Ocean was subducted under western Laurentia, Wrangellia approached the western side of the continent in oblique, clockwise fashion. The debate as to where the southern margin of the superterrane made initial contact and how it translated along the coast after docking is beyond the scope of this paper; see Umhoefer and Blakey (2006) and Wyld et al. (2006) for extended discussion. North of a transform that likely marked the northern margin of the Insular superterrane, the Koyukuk arc approached Arctic Alaska in the Late Jurassic (Nokleberg et al. 2000; Nelson et al. 2013; Shephard et al. 2013; Amato et al. 2015). The history of this arc is unclear, but if the Uda-Murgal arc extended along the western margin of the Angayucham Ocean (Shephard et al. 2013) as shown of Figure 10, then the arc likely formed in one of three ways: 1) subduction reversal on the UdaMurgal arc followed by closure of the Angayucham Ocean and accretion to Arctic Alaska, 2) west-directed intraplate subduction within the Angayucham Ocean, or 3) slab rollback of Panthalassa along the Uda-Murgal arc, generating a back-arc extension of the arc with the rifted arc becoming the east-facing Koyukuk arc. Regardless of origin, the Koyukuk arc migrated eastward across and subducted the Angayucham Ocean (Fig. 11) and then accreted to Arctic Alaska in the Late Jurassic (Nokelberg et al. 2000). During accretion, subduction direction reversed and Arctic Alaska was bounded on the west by a west-facing arc (Nokleberg et al. 2000; Shephard et al. 2013). The significance of this is discussed in the Early Cretaceous section.

In eastern Russia, the Uda-Murgal and Alazeya-Oloy arcs formed a U-shaped subduction zone along the margins of Kolyma-Omolon (Fig. 11A). The South Anyui Ocean was subducted beneath both the Alazeya-Oly and Nutesyn arcs and began to close (Nokleberg et al. 2000; Shephard et al. 2013; Amato et al. 2015). By the end of the Jurassic, three important ocean plates, the South Anyui, the Angayucham, and Panthalassa were either greatly reduced in size or totally subducted and the Farallon Plate was in contact with western Laurentia (Fig. 12). This event is marked by a distinct change from continent-derived sediment to sediment derived from arc terranes and orogenic belts (Miller et al. 2017).

East of AACM, the circum-Arctic region was less affected by tectonic events although rifting in the NorwegianGreenland seaway opened a marine connection between the Barents Shelf and the embryonic central Atlantic Ocean (Sibuet et al. 2012). Continental rifting at $170 \mathrm{Ma}$ in the Sverdrup Basin (Embry and Beauchamp 2008) may be related to early opening of the Canada Basin (see below). A steady rise in sea level coupled with several new areas of subsidence flooded broad areas in Siberia and Baltica and connected the Barents Shelf southward into the Caspian 

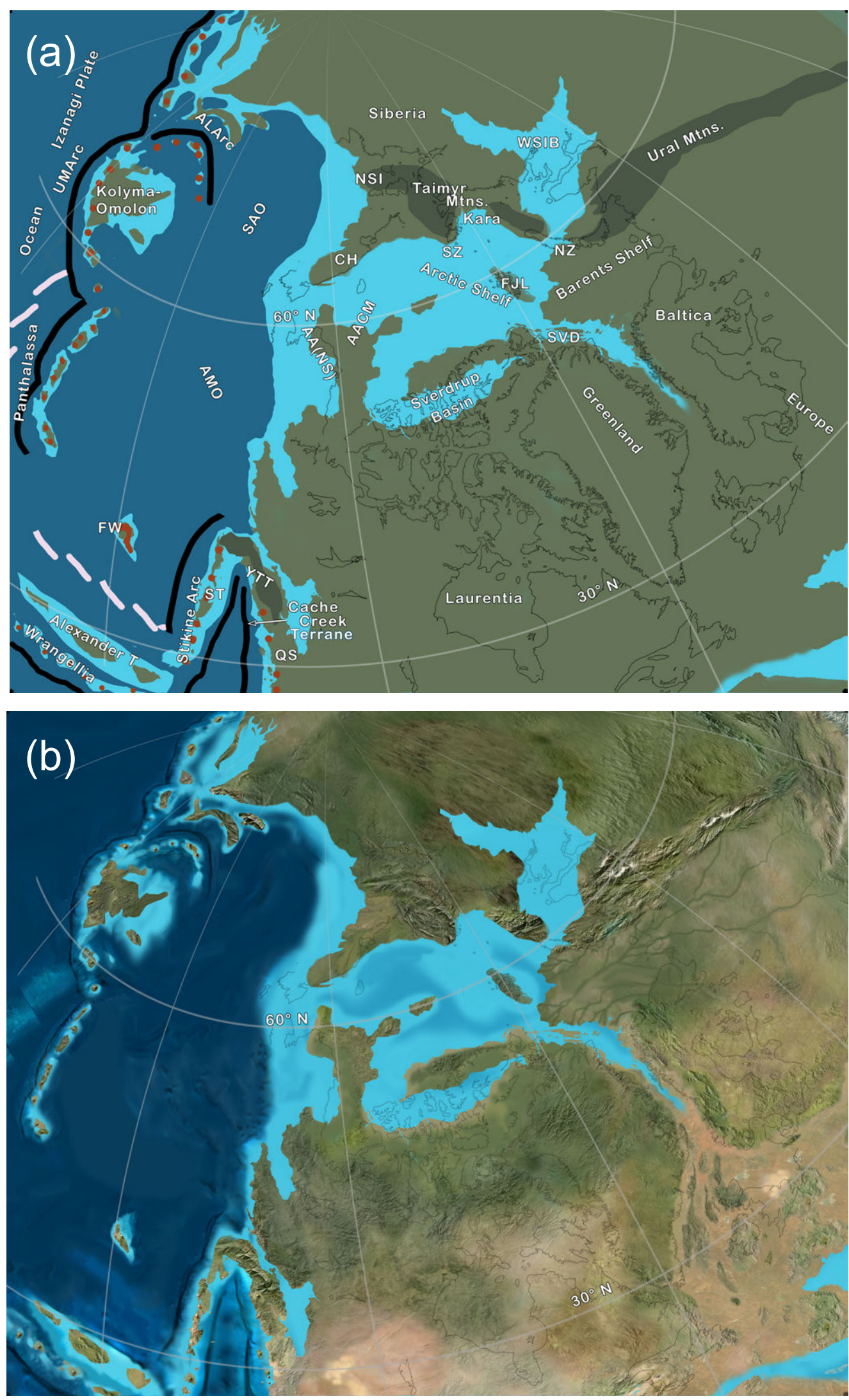

Figure 10. Late Triassic-Early Jurassic (ca. $200 \mathrm{Ma}$ ) paleotectonics and paleogeography showing developing arc systems along Panthalassa margin. See text for data sources for the maps. Centre of orthographic projection $50^{\circ} \mathrm{N}, 10^{\circ} \mathrm{W}$ (graticule of Seton et al. 2012). (a) Paleotectonic map. (b) Hypothetical paleogeography; see text for description of features and discussion. Note large deltaic area across the Barents Shelf. 

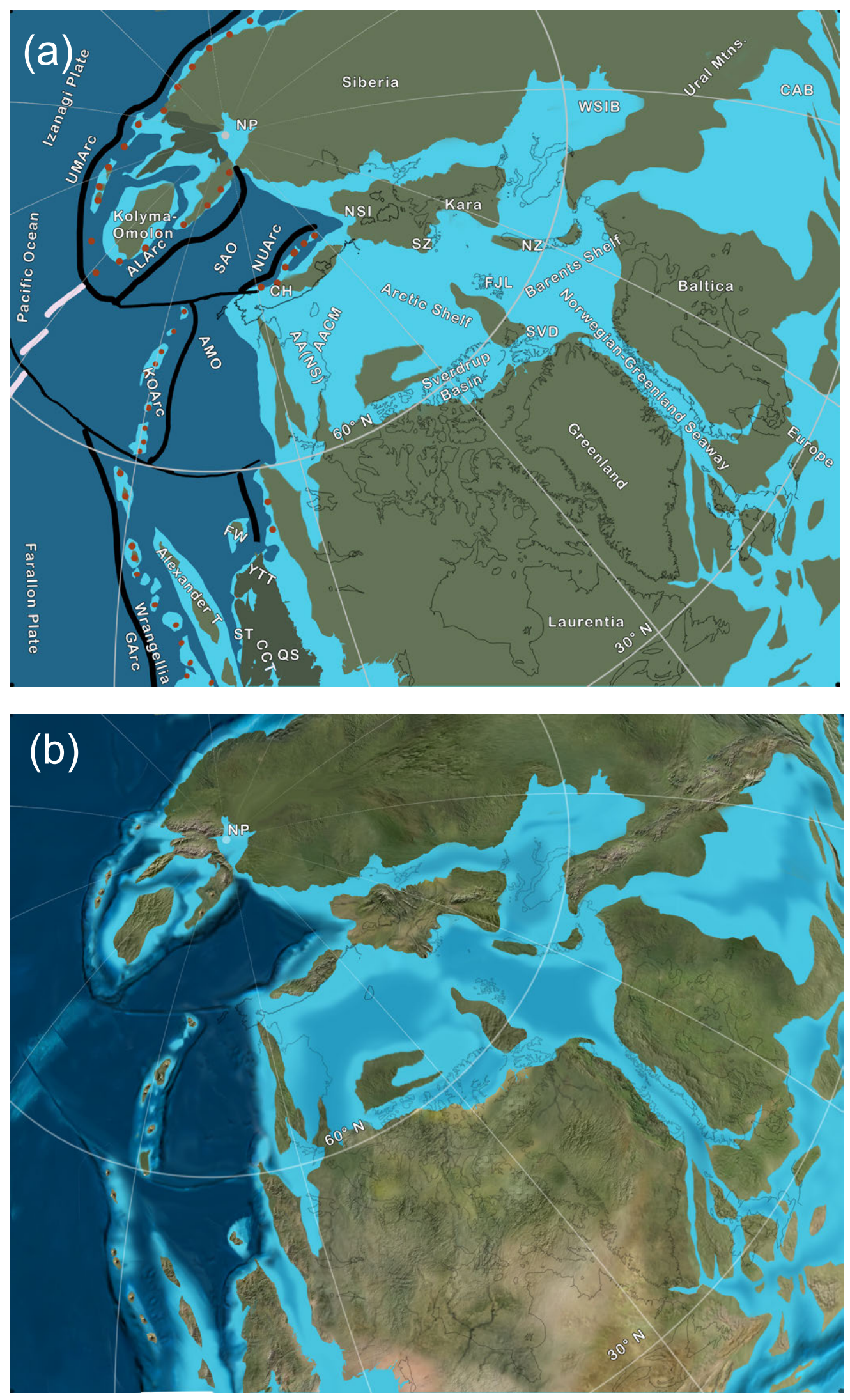

Figure 11. Middle Jurassic (ca. $170 \mathrm{Ma}$ ) paleotectonics and paleogeography showing arc and subduction zone complexes along the Panthalassa margin. See text for data sources for the maps. Centre of orthographic projection $60^{\circ} \mathrm{N}, 10^{\circ} \mathrm{W}$ (graticule of Seton et al. 2012). (a) Paleotectonic map. (b) Hypothetical paleogeography; see text for description of features and discussion. 
Basin (Ziegler 1988). Sedimentary facies in the Arctic and Barents shelves reflect land-sea paleogeography, with coastal plain and shoreline-shallow marine sands bordering land regions and grading seaward into muds and thin carbonates (Ziegler 1988; Embry and Beauchamp 2008; Smelror et al. 2009). The West Siberian Basin evolved during the Jurassic from a small, shallow basin to a broad, epicontinental sea with deep marine deposits in the centre; its sedimentary fill reflects the erosional history of the Urals from high-relief mountains to low-relief uplands (Kontorovich et al. 2013).

\section{Early Cretaceous}

By the close of the Jurassic, the tectonic framework was set for the culmination of events that would shape the modern circum-Arctic region (Fig. 12). Subduction ruled the Pacific margin and the myriad of arcs, subduction zones, small ocean plates, and microcontinents that dominated the Jurassic (Nokleberg et al. 2000) merged with, or were subducted beneath, the North American and Siberian continents (Figs 12-14). The AACM was bordered on the Pacific margin by a subduction zone that extended from Antarctica, along the Americas, around Arctic Siberia, around Japan, China, southeastern Asia, and along the northern margin of the Tethys Ocean to southern Europe (Seton et al. 2012). During the evolution of the part of this subduction system along the circum-Arctic region, AACM rotated and transformed towards the Pacific margin, and the Amerasia Basin opened (Fig. 14). A number of models have been proposed to explain this evolution from a western Pacific-style margin to an Andean-style margin during the Late Jurassic and the Early Cretaceous (see review of older models in Lawver and Scotese 1990 and reviews of more recent models in Shephard et al. 2013 and Amato et al. 2015).

As the Koyukuk arc migrated eastward to close the Angayucham Ocean (Till 2016), the northern margin of Arctic Alaska remained passive (Fig. 11). By 142.6 Ma the arc accreted to Arctic Alaska and subduction reversed to east dipping under southern AACM (Nokleberg et al. 2000; Shephard et al. 2013), while farther north along the northern margin of AACM, east-dipping subduction generated the Nutesyn arc on Chukotka (Parfenov 1997). As subduction progressed along the length of AACM, back-arc extension and slab roll-back may have initiated the opening of the Amerasia Basin, although rifting along the Lomonosov margin may date back to Early Jurassic (195 Ma; Shephard et al. 2013). Also, during the Late Jurassic, the Kolyma-Omolon terrane collided with the Verkhoyansk passive margin to initiate the Verkhoyansk orogen, which continued through the Early Cretaceous (Shephard et al. 2013; Amato et al. 2015). Subduction under both flanks of the South Anyui Ocean caused it to close and resulted in the collision of Chukotka with Kolyma-Omolon and the Chukotka fold belt (Shephard et al. 2013).

The tectonic model for the opening of the Amerasia Basin that is preferred here is shown on Figs. 12-13 and follows the events outlined by Shephard et al. (2013). This model is chosen for its relative simplicity and because it allows the integrity of the AACM to be maintained throughout the late Paleozoic to present as shown on the paleogeographic and paleotectonic maps herein. Furthermore, the model is compatible with the global plate-tectonic models of Domeier and Torsvik (2014) for the Paleozoic and Seton et al. (2012) for the Mesozoic and Cenozoic that are followed here. The Shephard et al. model is a hybrid between the simple rotational or windshield wiper model (Carey 1955; 1958; Grantz et al. 1993) and transform/strike-slip model (Lane 1997) and involves components of both at various times during the protracted events that opened the Amerasia Basin. The model initiated with transform movement as early as 195 $\mathrm{Ma}$ and evolved to a spreading event by $142 \mathrm{Ma}$, at which time a transform developed across AACM (Fig. 12) and the two blocks moved independently. The northern block, the East Siberia microplate (Shephard et al. 2013), rotated and transformed towards Kolyma-Omolon to close the South Anyui Ocean while the southern block, the North Slope microplate, underwent rotation to open the Canada Basin and later collide with terranes along the Pacific subduction zone to generate the Brookian orogeny at $125 \mathrm{Ma}$ (Moore et al. 2002; Till 2016).

Another important Early Cretaceous event was the emplacement of the High Arctic Large Igneous Province (HALIP), a controversial region of thick ocean crust in the eastern Amerasia Basin, probably an oceanic plateau, that may overlie stretched continental crust or stranded continental fragments (Pease et al. 2014; Petrov et al. 2016). The age of the HALIP spans 130-70 Ma (Petrov et al. 2016). In addition to the Amerasia Basin, the HALIP covers major parts of the Northern Barents and Kara shelves. Further, it is adjacent to and partly overlaps the Chukchi Borderlands, where highly extended continental crust formed during translation of the AACM (Pease et al. 2014).

Lower Cretaceous sedimentary rocks are widely distributed across the circum-Arctic region and consist almost exclusively of siliciclastics. Across the Barents Shelf and west Siberian Basin regions, mudstones were deposited in offshore shelf and basin areas, condensed limestones accumulated on structural highs, and sandstones formed in shoreline and nearshore areas (Ziegler 1988; Embry and Beauchamp 2008; Smelror et al. 2009). In the Arctic Alaska region, the Early Cretaceous marks the beginning of the Brookian tectonostratigraphic sequence in which sediments were shed off of the Brooks Range onto the passive margin of the Alaska North Slope (Houseknecht et al. 2009). Sedimentary source to sink direction was opposite to that of Mississippian to Jurassic clastic deposits. Lower Cretaceous sedimentary rocks of eastern Siberia and northeastern Russia reflect the active tectonic events present across the region. The collision of Kolyma-Omolon with Siberia generated the Verkhoyansk Mountains and the Verkhoyansk foreland basin along eastern Siberia. Fans shed coarse sediment into the basin, into which at times shallow marine seas penetrated (Amato et al. 2015). The Chukotka region has scattered sandstone and mudstone with interbedded volcanics that reflect the change 

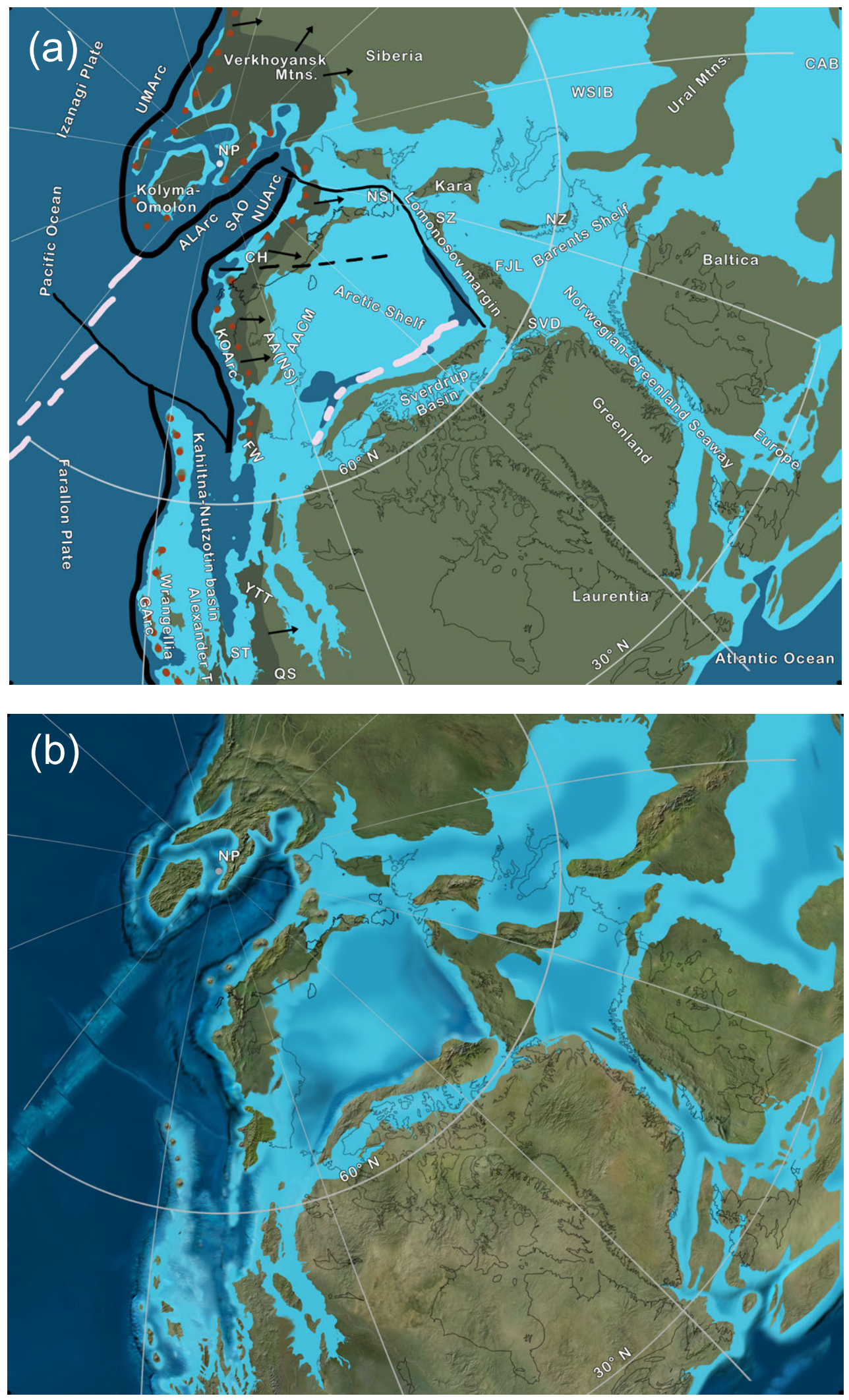

Figure 12. Early Cretaceous (Berriasian, ca. $140 \mathrm{Ma}$ ) paleotectonics and paleogeography showing initial opening of Canada Basin. See text for data sources for the maps. Centre of orthographic projection $75^{\circ} \mathrm{N}, 10^{\circ} \mathrm{W}$ (graticule of Seton $e t$ al. 2012). (a) Paleotectonic map. Dashed black line shows area of probable transform/transpressional movement between Chukotka and Arctic Alaska; black arrows show sediment transport directions. The accretion of numerous arcs and associated uplift caused the major change in sediment source areas. (b) Hypothetical paleogeography; see text for description of features and discussion. 

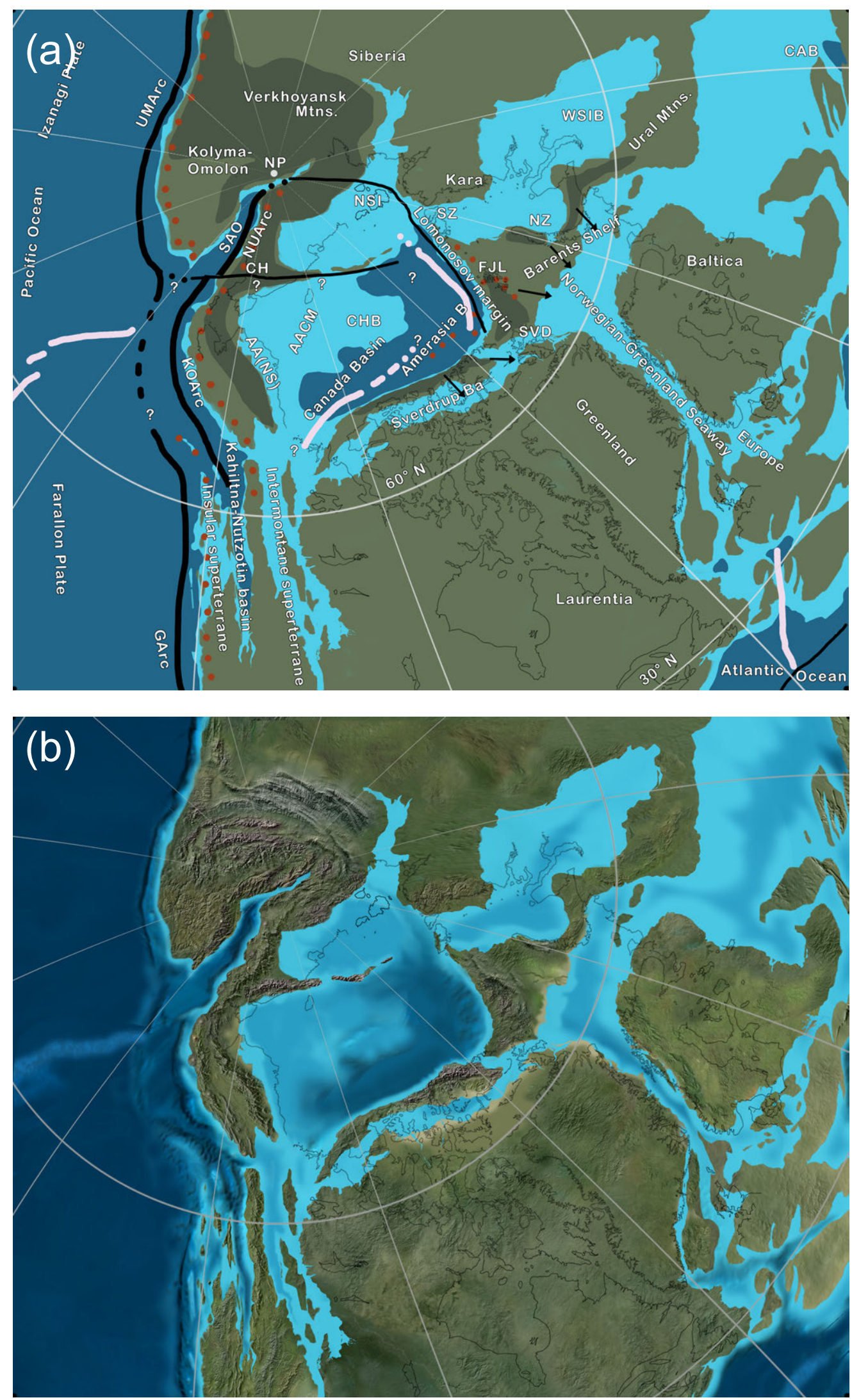

Figure 13. Early Cretaceous (Barremian, ca. $130 \mathrm{Ma}$ ) paleotectonics and paleogeography showing progressive opening of Canada Basin. See text for data sources for the maps. Centre of orthographic projection $75^{\circ} \mathrm{N}, 10^{\circ} \mathrm{W}$ (graticule of Seton $e t$ al. 2012). (a) Paleotectonic map. Queries show areas of uncertain tectonic restoration related to opening of Canada Basin; see text. (b) Hypothetical paleogeography; see text for description of features and discussion. 

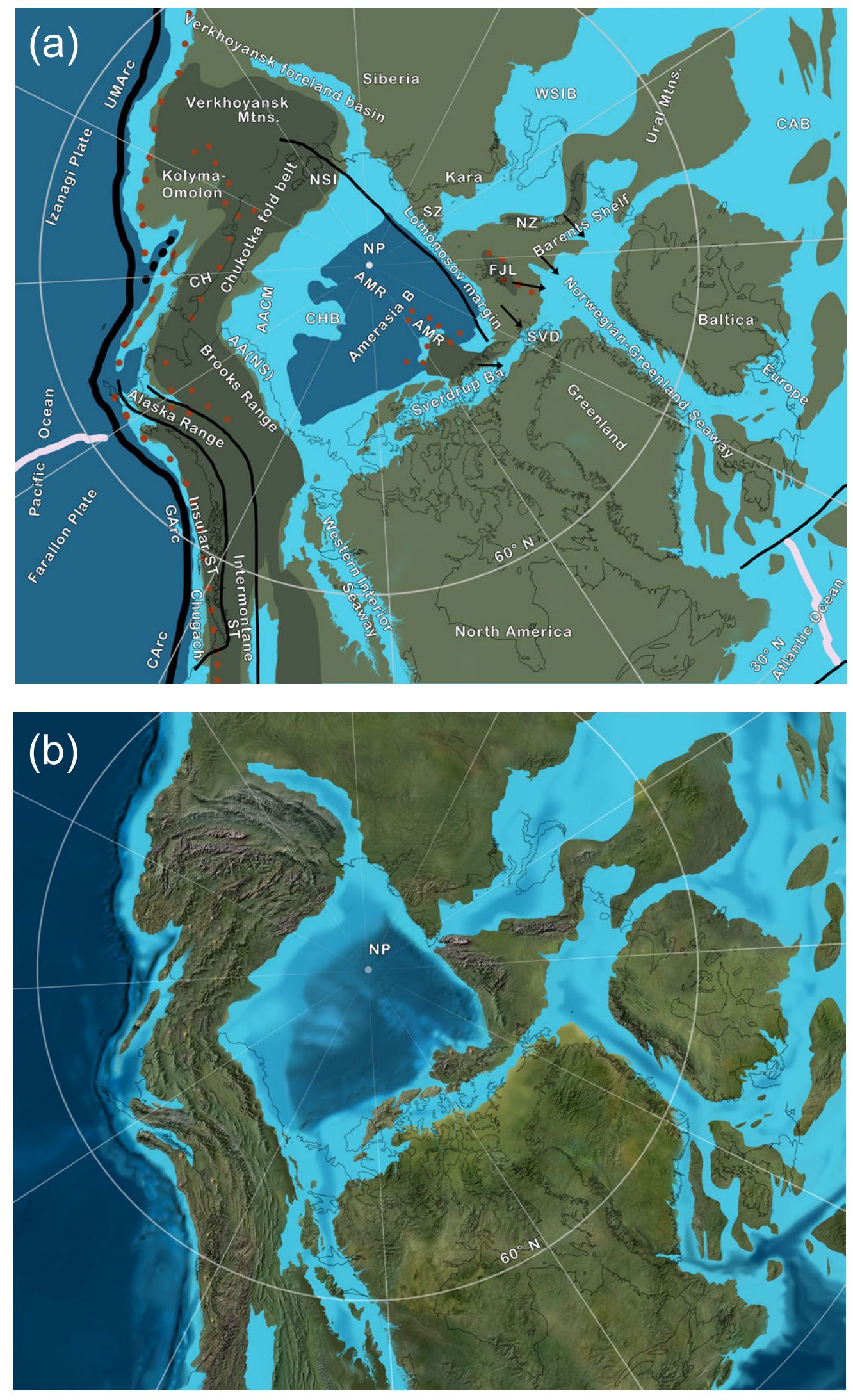

Figure 14. Middle Cretaceous (Albian, ca. $110 \mathrm{Ma}$ ) paleotectonics and paleogeography showing full opening of Canada Basin and closing of South Anyui Ocean. See text for data sources for the maps. Centre of orthographic projection North Pole (graticule of Seton et al. 2012). (a) Paleotectonic map. (b) Hypothetical paleogeography; see text for description of features and discussion. 
from continental areas to orogenic arc and orogenic areas (Miller et al. 2017). Arc sequences dominate the Pacific margin as documented by widespread volcanic-plutonic belts, blueschist facies metamorphism, flysch deposits, and fore-arc melange (Nokleberg et al. 2000).

\section{Late Cretaceous}

In many areas, Late Cretaceous tectonism and paleogeographic patterns continued from the Early Cretaceous (Figs. 15, 16). By Late Cretaceous, the Amerasia Basin was fully opened, the Western Interior Seaway connected the Arctic with the Gulf of Mexico, and global sea level was at an all-time high so that large portions of the North American, Baltic, and Siberian cratons were flooded by epicontinental seas (Fig. 15). As the Izanagi and Farallon plates continued to subduct under North America and Siberia/northeastern Russia, Andean-style arc activity continued along the Pacific margin of the circum-Arctic region, and the Insular superterrane was fully accreted to North America by $95 \mathrm{Ma}$ (Nokleberg et al. 2000). The newly formed Amerasia Basin was bordered by mountains towards the Pacific (AACM) margin and a series of islands and upland continental masses along its southern and eastern margins. The Norwegian-Greenland Sea, the Sverdrup Basin, and the West Siberian Basin all continued to be active and received clastic sediments. Tectonic activity occurred across Kolyma-Omolon and Chukotka.

The rotation of Arctic Alaska created a sharp reentrant along the southeastern Alaska coast to form a "backstop" that the Insular and Intermontane superterranes pushed against as transform faults caused their northward migration. In the region of sharpest bending, uplift was most intense as exemplified in the Alaska Range (Manuszak et al. 2007), where thrusting and uplift began in the Late Jurassic and Early Cretaceous and continued through the Late Cretaceous and Cenozoic. Along much of the Alaska Range, the outer Insular superterrane was thrust under the Intermontane superterrane; weak rocks that formed in Jurassic and Early Cretaceous flysch basins (e.g. Kahiltna and Nutzotin) between the two superterranes were intensely folded and thrusted (Trop and Ridgway 2007; Nelson et al. 2013).

Upper Cretaceous sedimentary rocks range widely in composition and thickness across the circum-Arctic region. Foreland basin deposits across the Alaska North Slope and Verkhoyansk regions received sediment from adjacent mountain ranges, where coarse clastics grade distally into fine-grained, deepwater deposits. Clastic sediments in the West Siberian Basin, Barents Shelf, Norwegian-Greenland Seaway, Sverdrup Basin, and Western Interior Seaway range from shoreline sand to offshore sand and mud, to deepwater muds (Ziegler 1988; Embry and Beauchamp 2008). Abyssal muds and clays formed across much of the Amerasia Basin. Along the Pacific active margin, complex fore-arc and inter-arc basins received clastic deposits in submarine fan, slope, and abyssal environments (Sample and Reid 2003; Trop and Ridgway 2007). Arc volcanic rocks were spread over broad regions and are commonly interbedded with sedimentary rocks.

\section{Paleogene}

Two major tectonic processes affected the circum-Arctic region in the Paleogene: (1) sea-floor spreading related to the central Atlantic system expanded northward into the Labrador Sea and Baffin Bay, along the eastern margin of Greenland, and along the Lomonosov margin of the Arctic Ocean; and (2) plate reorganization in the Pacific Ocean modified subduction zones, opened the Bering Sea, and accreted Kamchatka to Kolyma-Omolon (Fig. 17). As Paleogene sea-floor spreading opened the Labrador Sea and Baffin Bay and separated Greenland from North America, the resulting rotation of northwest Greenland into the eastern Canadian Arctic Islands and Svalbard generated the Eurekan orogeny (Harrison et al. 1999). The rifting between Greenland and Baltica separated the two long-joined regions to form the North Atlantic Ocean. Coincident with the opening of the North Atlantic were the migration of the Iceland hotspot and the formation of a mantle plume that generated huge volumes of volcanic rocks that maintained a link between Greenland and the northern British Isles (Eberle and Greenwood 2012). The formation of a mid-ocean ridge along the Lomonosov margin of northern Eurasia opened the Eurasian Basin and separated the Lomonosov Ridge from the adjacent continent (Rowley and Lottes 1988; Sauermilch et al. 2018).

The reorganization of Pacific Ocean plates is a controversial topic, based mostly on the presence of synthetic plates (i.e. plates necessary to satisfy a given model that are now completely subducted) such as Kula and Izanagi (Seton et al. 2012). Each of the oceanic plates had different platevector motions with respect to North America and Asia that caused variation laterally along the subduction zone that bordered North America and Russia. After Kamchatka accreted to Kolyma-Omolon in the Late Cretaceous to Paleocene (Geist et al. 1994; Shephard et al. 2013), subduction jumped seaward of the collision zone, and Kamchatka rotated and partly pulled away from the adjacent continent in the Eocene (Shephard et al. 2013). Along the Chukotka and Alaska coasts, slab roll-back formed the Bering Sea and the Aleutian Arc during the Eocene (Jicha et al. 2006).

The combined effect of these tectonic events isolated the Arctic Ocean from the global ocean (Fig. 17) as documented by Middle Eocene flora, the free-floating freshwater fern Azolla (Brinkhuis et al. 2006), and fauna that indicate extensive fresh water in the Arctic and a close affinity in the vertebrate fauna between North America and both Europe and Siberia (Eberle and Greenwood 2012). The Siberia-Alaska land bridge extended through Beringia along the extensive arc-related volcanic chains and the North America-Greenland-Iceland-Europe connection followed tectonic ridges in the Eurekan Mountains and the volcanic landmasses generated by the Iceland hotspot in the embryonic North Atlantic (Fig. 17). Furthermore, at times the long-lasting marine 

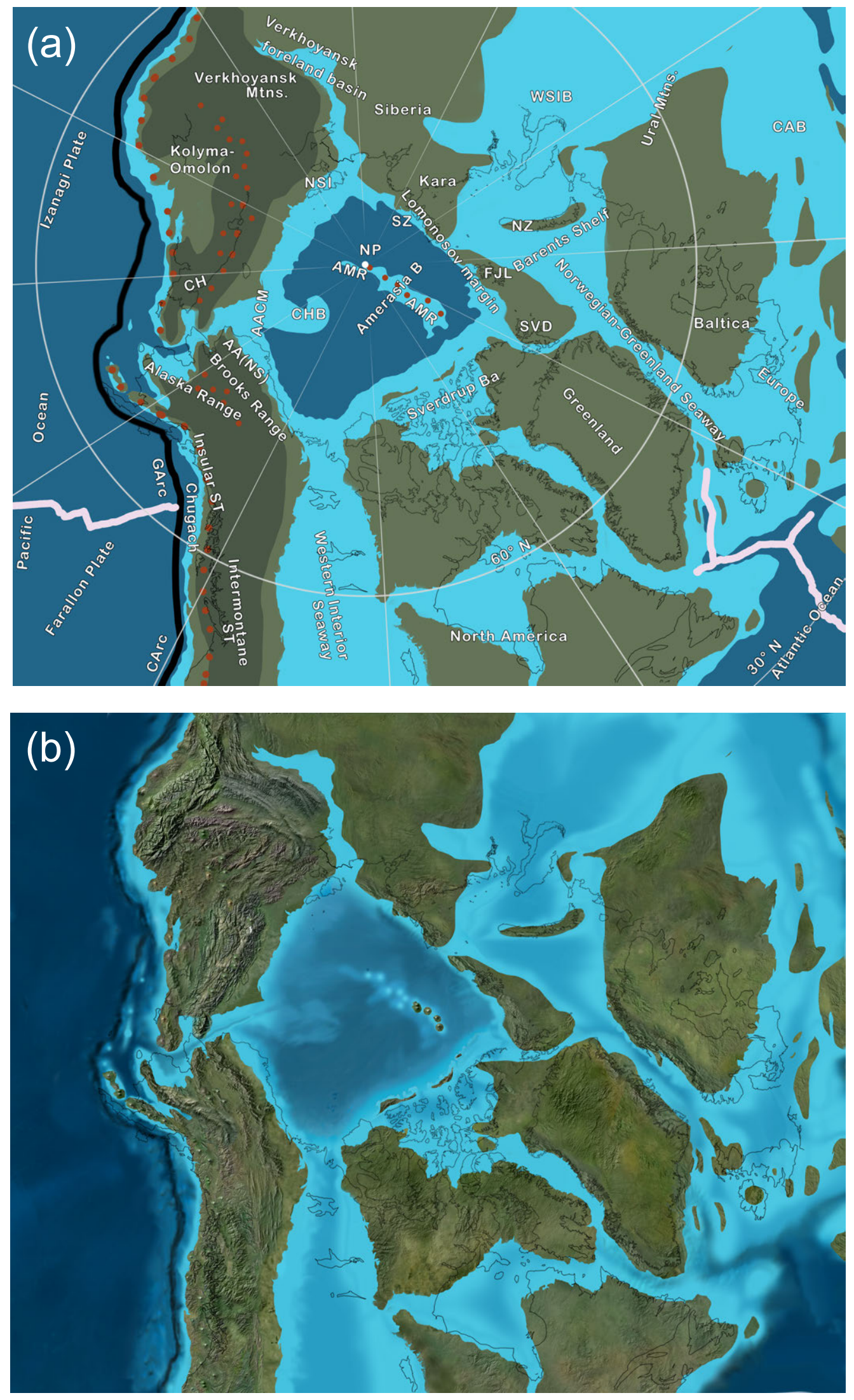

Figure 15. Late Cretaceous (Turonian ca. $90 \mathrm{Ma}$ ) paleotectonics and paleogeography showing major eustatic high-stand with numerous connections of Arctic Ocean with global oceans. See text for data sources for the maps. of orthographic projection North Pole (graticule of Seton et al. 2012). (a) Paleotectonic map. (b) Hypothetical paleogeography; see text for description of features and discussion. 

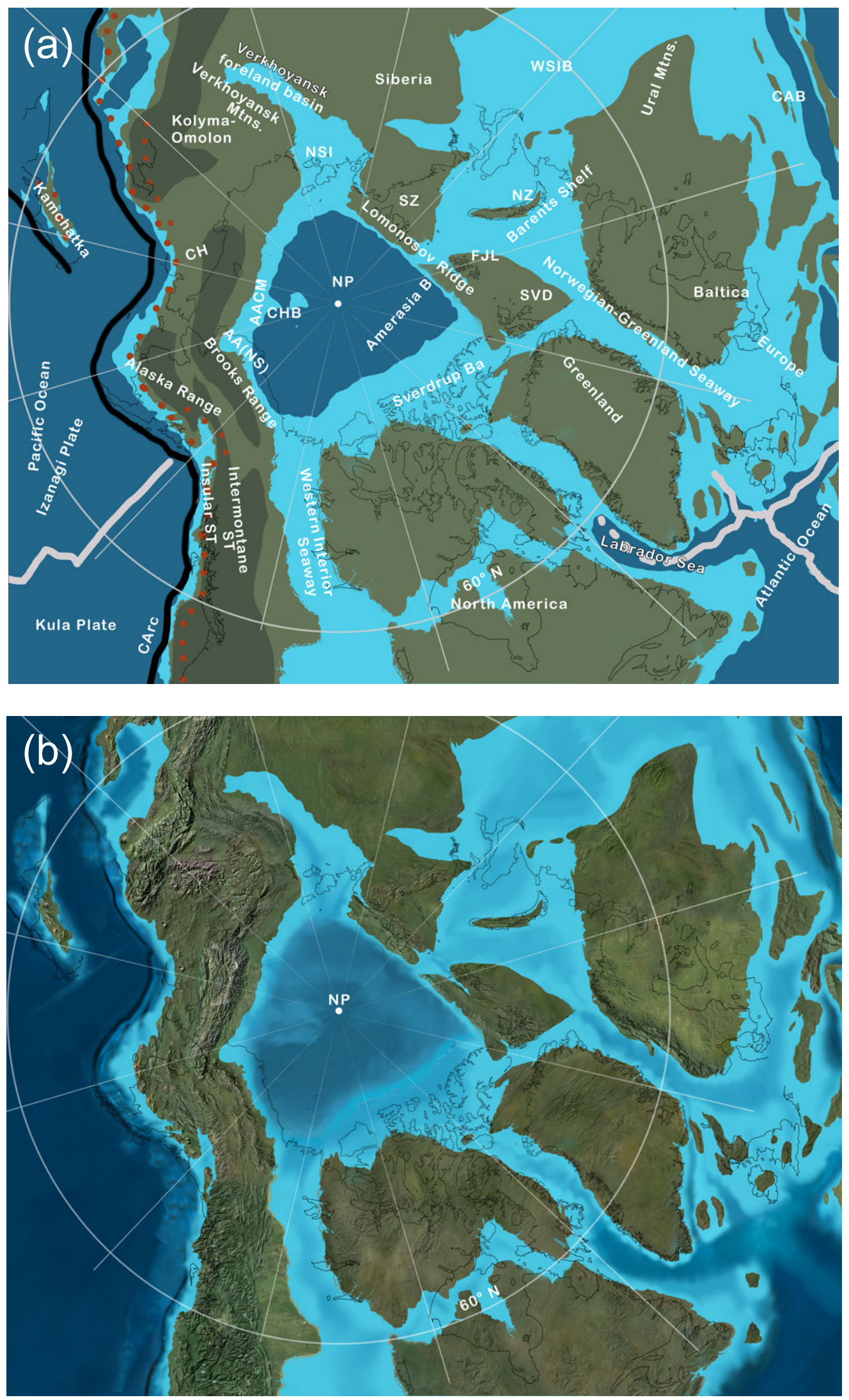

Figure 16. Late Cretaceous (Maastrichtian ca. $70 \mathrm{Ma}$ ) paleotectonics and paleogeography showing opening of Labrador Sea and rotation of Greenland from eastern North America. See text for data sources for the maps. Centre of orthographic projection North Pole (graticule of Seton et al. 2012). (a) Paleotectonic map. (b) Hypothetical paleogeography; see text for description of features and discussion. 

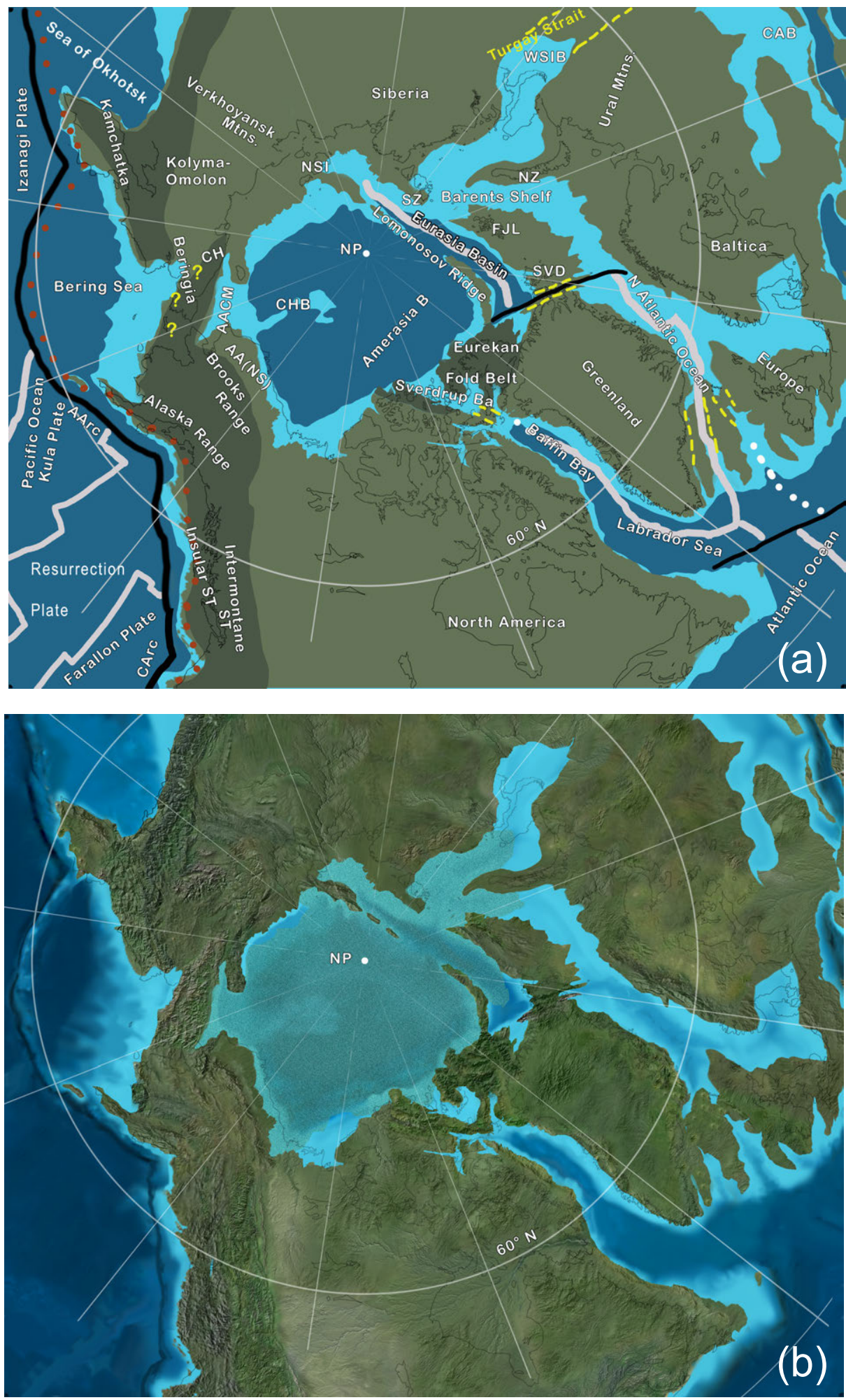

Figure 17. Middle Eocene (ca. $50 \mathrm{Ma}$ ) paleotectonics and paleogeography showing initial opening of Eurasia Basin and North Atlantic Ocean; note restriction of Arctic Ocean. See text for data sources for the maps. Centre of orthographic projection North Pole (graticule of Seton et al. 2012). (a) Paleotectonic map. This time slice shows the Arctic isolated from the global ocean as the Turgay Strait across Siberia was closed. The yellow dashed lines indicate regions that were periodically opened and closed, affecting connection of the Arctic Ocean with the global ocean. The queries across Beringia suggest possible connections to the Pacific Ocean at various times in the Paleogene. (b) Hypothetical paleogeography. Note the probable large rivers that brought large amounts of fresh water to the Arctic, especially across Siberia. The greenish cast across the Arctic Ocean shows the Azolla free-floating fern choking Arctic surface waters; see text for description of features and discussion. 
connection from the Barents Shelf through the West Siberian Basin and into the Tethyian realm, the Turgay Strait, was closed, causing additional restriction of the Arctic Ocean (Ziegler 1988; Brinkhuis et al. 2006; Eberle and Greenwood 2012).

Following Late Cretaceous to Early Paleocene erosion, upper Paleogene marine deposition continued across the West Siberian Basin, Barents Shelf, and Svalbard (Smelror et al. 2009; Smelror and Petrov 2018); especially thick Late Paleocene to Oligocene marine rocks blanket the western Barents Shelf (Smelror et al. 2009). In the Paleocene, the Sverdrup Basin became dismembered as the Eurekan orogen progressed and thick, localized, clastic deposits mark the demise of the basin (Embry and Beauchamp 2008). Paleogene deposition in the Brooks Range foreland basin shifted distally as uplift and erosion modified the basin and formed a major post-Cretaceous unconformity (Houseknecht $e t$ al. 2009).

Volcanic and volcaniclastic rocks dominate the Pacific margin of the circum-Arctic region and include various arc volcanic rocks and plutons, back-arc and fore-arc volcanic rocks and sediments, trench, melange, and accretionary prism units, and oceanic deposits including scattered ophiolites. Active arc and subduction zone tectonics, including large transform faults, suggest rugged, evolving topography. The Bering land bridge connected Alaska and Chukotka for much of the Paleogene, although dynamic tectonic activity may have caused breaks in the bridge at times (Eberle and Greenwood 2012). The Cretaceous-Paleogene history of Kamchatka involved the accretion of several arcs and other oceanic material that expanded the Kolyma-Omolon and Chukotka-Pacific margins (Geist et al. 1994). Subsequent rotation and rifting formed the back-arc Sea of Okhotsk (Shephard et al. 2013). Large right-lateral transform faults facilitated the northward transport of the Intermontane and Insular superterranes and increased the breadth of Alaska and generated significant uplift of the Alaska Range (Trop and Ridgway 2007).

\section{Neogene}

During the Neogene, the Mesozoic and early Cenozoic marine basins and shelves, including the West Siberian Basin, Barents Shelf (Miocene-Early Pliocene), Sverdrup Basin, and the Brooks Range foreland basin were above sea level and the expanding North Atlantic Ocean and Eurasian Basin provided the main connection between the Arctic Ocean and the global ocean (Fig. 18). Sea-floor spreading between Greenland and Canada ended by $33 \mathrm{Ma}$ (Torsvik and Cocks 2017) and tectonic activity waned in the Eurekan orogen. The Aleutian Arc was the site of immense volcanic activity (Jicha et al. 2006) as the Bering Plate expanded due to the rotation of Alaska and dextral transform faulting (Nokleberg et al. 2000). During the Late Pliocene and Quaternary, the Beringia land bridge opened and closed in response to glacially induced eustatic sea-level changes. Large transform faults continued to affect southern Alaska and adjacent parts of Canada and generated the tallest mountains in North America (Nelson et al. 2013).

Neogene marine clastic sedimentation was restricted to shelves that rimmed the Arctic Ocean and the bathyal and abyssal areas of the ocean basin as well as fore-arc regions of the Pacific margin and the back-arc Bering Sea (Nokleberg et al. 2000). Fluvial sediments across central and northeastern Canada define a large continental-scale river system, the Bell River system, which drained over half of North America and emptied into the Labrador Sea (Sears 2013). Equally large rivers across Russia drained northward into the Arctic (Ershova et al. 2016).

Although the onset of major glaciation in the Arctic region continues to be debated (Alley et al. 2010), Pleistocene continental and alpine ice sheets are widespread. The largest areas of continental glaciation were centred across Greenland, the Hudson Bay region, and the Baltic region. Major episodes of Cenozoic uplift and erosion are documented from some regions in the Arctic, and sedimentary sequences reaching 2-4 km have been exhumed and removed. This is particularly evident in the North Atlantic region and on the Barents and Kara shelves, where the effects of these processes on petroleum reservoirs have been studied in detail (see references in Smelror and Petrov 2018).

Glaciation of much of Alaska and Siberia was restricted to Alpine areas, apparently because these regions were too dry to support continental ice sheets (Alley et al. 2010). Although many of the large channel and fiord regions of the greater Arctic region are or were occupied by glaciers during the latest Cenozoic, many were initially carved by fluvial processes, not glaciers (England 1987). As the last continental glaciers retreated 6-10 Ka, the modern circum-Arctic landscape unfolded. Today, the study of circum-Arctic glaciers, their history, causes, effects on the landscape including glacial rebound, and climate form one of the most important areas of scientific endeavor.

\section{SUMMARY}

The circum-Arctic region comprises a region of complex and relatively poorly understood geologic history, at least in an overview sense. Severe climate and the resulting inaccessibility and politics are the prime factors that inhibit Arctic studies. Although recent geologic interest in the region has generated a huge mass of literature, most published works have focused either on specific areas or slices of geologic time. This study has attempted to orchestrate this body of geologic literature into a comprehensive presentation of over 400 million years of geologic history across the entire circum-Arctic region. The saga begins with the Silurian and Devonian accretion of terranes along the northern margin of Laurussia during the Caledonian and Ellesmerian orogenies and the assembly of the Arctic Alaska Chukotka microcontinent. Ensuing assembly of Pangea during the Carboniferous and Permian joined Siberia and peri-Siberian terranes to Laurussia. Mesozoic subduction, 

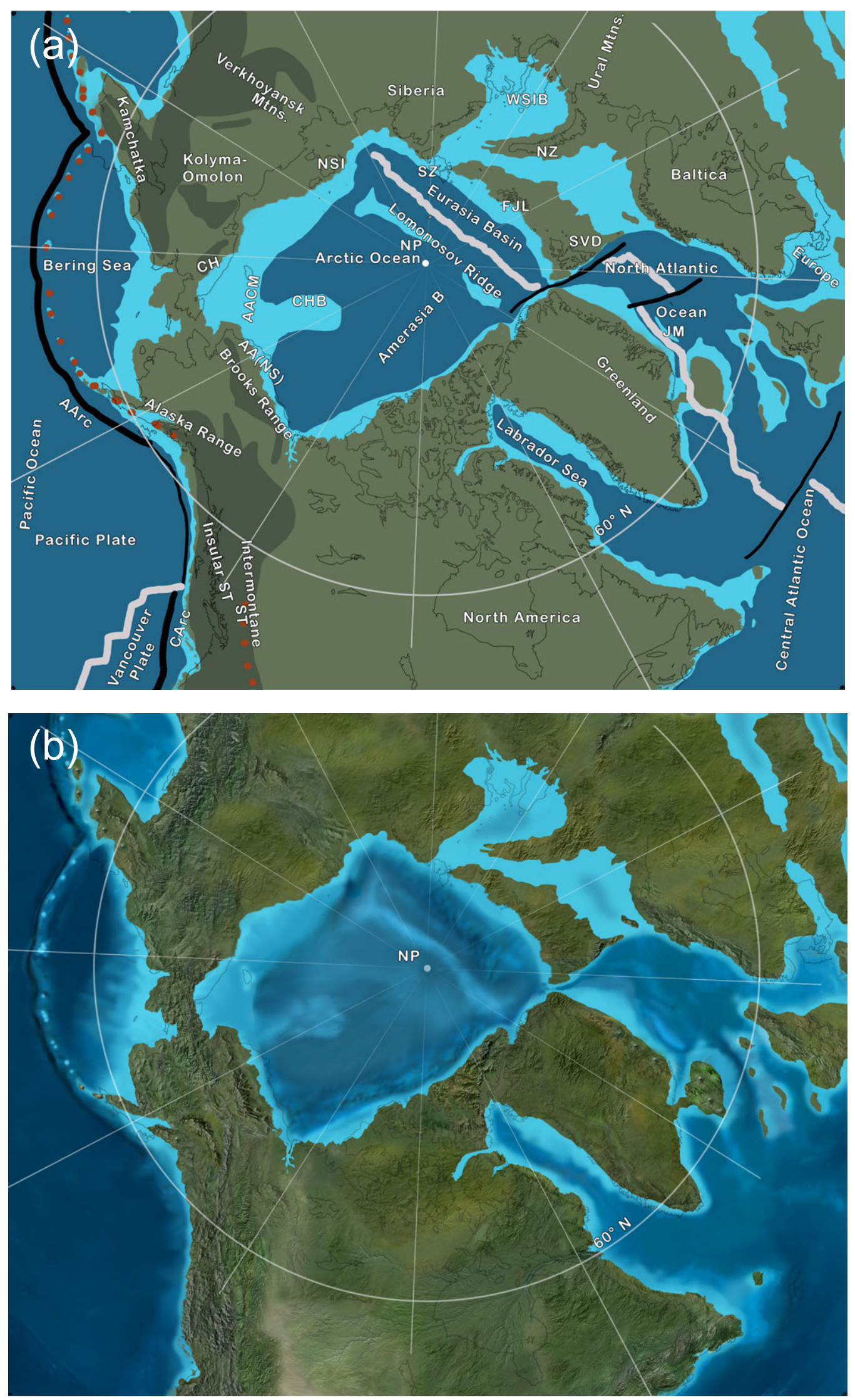

Figure 18. Early Miocene (ca. $20 \mathrm{Ma}$ ) paleotectonics and paleogeography showing widening of Eurasia Basin and North Atlantic Ocean. See text for data sources for the maps. Centre of orthographic projection North Pole (graticule of Seton et al. 2012). (a) Paleotectonic map. (b) Hypothetical paleogeography; see text for description of features and discussion. 
arc tectonics, and terrane accretion led to the formation of a contiguous Cordilleran-style Pacific margin and the JurassicCretaceous opening of the Canada Basin. Late Mesozoic and Cenozoic sea-floor spreading in the greater North Atlantic region separated Europe and North America and led to the opening of the Eurasian Basin and the final growth of the Arctic Ocean. Pleistocene glaciation completed the landscape evolution of the circum-Arctic and left the youngest deposits in the region.

\section{ACKNOWLEDGMENTS}

Jonathan Bujak and Rob Fensome encouraged me to prepare this chapter for the Circum-Arctic volume. Discussions with Owen Anfinson greatly helped my understanding of Arctic geologic events and their timing. Morten Smelror provided a critical review of an earlier version that greatly improved the paper. Maurice Colpron and Elizabeth Miller provided thorough reviews and much information that especially helped me to provide this paper with the latest interpretations of Arctic geologic history. Rob Fensome performed a critical editing of the manuscript.

\section{REFERENCES}

Alley, R.B., Andrews, J.T., Brigham-Grette, J., Clarke, G.K.C., Cuffey, K.M., Fitzpatrick, J.J., Funder, S., Marshall, S.J., Miller, G.H., Mitrovica, J.X., Muhs, D.R., Otto-Bleisner, B., Polyak, L., and White, J.W.C. 2010. History of the Greenland Ice Sheet: paleoclimatic insights. Quaternary Science Reviews, 29, pp. 1728-1756. https:// doi.org/10.1016/i.quascirev.2010.02.007

Alonso-Torres, D., Beauchamp, B., Guest, B., Hadlari, T., and Matthews, W. 2018. Late Paleozoic to Triassic arc magmatism north of the Sverdrup Basin in the Canadian Arctic: evidence from detrital zircon U-Pb geochronology. Lithosphere, 10, pp. 426-445. https://doi.org/10.1130/ $\underline{\mathrm{L} 683.1}$

Amato, J.M., Toro, J., Akinin, V.V., Hampton, B.A., Salnikov, A.S., and Tuchkova, M.I. 2015. Tectonic evolution of the Mesozoic South Anyui suture zone, eastern Russia: a critical component of paleogeographic reconstructions of the Arctic region. Geosphere, 11 (5), pp. 1530-1564. https:// doi.org/10.1130/GES01165.1

Anfinson, O.A., Leier, A.L., Embry, A.F., and Dewing, K. 2012. Detrital zircon geochronology and provenance of the Neoproterozoic to Late Devonian Franklinian Basin, Canadian Arctic Islands. Geological Society of America Bulletin, 124 (3-4), pp. 415-430. https://doi.org/10.1130/ B30503.1

Beranek, L.P., Pease, V., Scott, R.A. and Thomsen, T.B. 2013. Detrital zircon geochronology of Ediacaran to Cambrian deep-water strata of the Franklinian Basin, northern Ellesmere Island, Nunavut: implications for regional stratigraphic correlations. Canadian Journal of Earth Sci- ences, 50, pp. 1007-1018. https://doi.org/10.1139/cjes2013-0026

Beranek, L.P., Pease, V., Hadlari, T., and Dewing, K. 2015. Silurian flysch successions of Ellesmere Island, Arctic Canada, and their significance to northern Caledonian palaeogeography and tectonics. Journal of the Geological Society, 172 (2), pp. 201-212. https://doi.org/10.1144/ jgs2014-027

Brinkhuis, H., Schouten, S., Collinson, M.E., Sluijs, A., Sinninghe Damste, J.S., Dickens, G.R., Huber, M., Cronin, T.M., Onodera, J., Takahashi, K., Bujak, J.P., Stein, R., van der Burgh, J., Eldrett, J.S., Harding, I.C., Lotter, A.F., Sangiorgi, F., van Konijnenburg-van Cittert, H., de Leeuw, J.W. et al. 2006. Episodic fresh surface waters in the Eocene Arctic Ocean. Nature, 441, pp. 606-609. https://doi. org/10.1038/nature 04692

Carey, S.W. 1955. The orocline concept in geotectonics. Royal Society of Tasmania Proceedings, 89, pp. 255-288.

Carey, S.W. 1958. The tectonic approach to continental drift. In Proceedings, Continental drift, a symposium, Hobart, March, 1956: Hobart, University of Tasmania, pp. 177355.

Cocks, L.R.M. and Torsvik, T.H. 2005. Baltica from the late Precambrian to mid Palaeozoic: the gain and loss of a terranes's identity. Earth-Science Reviews, 72, pp. 39-66. https://doi.org/10.1016/j.earscirev.2005.04.001

Cocks, L.R.M. and Torsvik, T.H. 2011. The Palaeozoic geography of Laurentia and western Laurussia: a stable craton with mobile margins. Earth-Science Reviews, 106, pp. 1-51. https://doi.org/10.1016/j.earscirev.2011.01.007

Colpron M. and Nelson, J.L. 2009. A Palaeozoic Northwest Passage: incursion of Caledonian, Baltican and Siberian terranes into eastern Panthalassa, and the early evolution of the North American Cordillera. In Earth accretionary systems through space and time. Edited by P.A. Cawood and A. Kröner. Geological Society of London Special Publication 318, pp. 273-307. https://doi.org/10.1144/ SP318.10

Colpron, M. and Nelson, J.L. 2011. A Palaeozoic NW Passage and the Timanian, Caledonian and Uralian connections of some exotic terranes in the North American Cordillera. In Arctic petroleum geology. Edited by A.M. Spencer, A.F. Embry, D.L. Gautier, A.V. Stoupakova, and K. Sørensen. Geological Society of London Memoir 35, pp. 463-484. https://doi.org/10.1144/M35.31

Colpron, M., Nelson, J.L., and Murphy, D.C. 2007. Northern Cordilleran terranes and their interactions through time. GSA Today, 17, pp. 4-10. https://doi.org/10.1130/ GSAT01704-5A.1

Colpron, M., McClelland, W.C., and Strauss, J.V. 2018. Detrital zircon $\mathrm{U}-\mathrm{Pb}$ geochronological and $\mathrm{Hf}$ isotopic constraints on the geological evolution of North Yukon. In Circum-Arctic structural events: tectonic evolution of the Arctic margins and trans-Arctic links with adjacent orogens. Edited by K. Piepjohn, J.V. Strauss, L. Reinhart, and W.C. McClelland. Geological Society of America Special Paper 541, pp. 397-437. https://doi. 
org $/ 10.1130 / 2018.2541(19)$

Cook, T.D. and Bally, A.W. 1975. Stratigraphic atlas of North and Central America. Princeton University Press, Princeton, New Jersey, $271 \mathrm{p}$.

Dewing, K., Hadlari, T., Pearson, D.G., and Matthews, W. 2019. Early Ordovician to Early Devonian tectonic development of the northern margin of Laurentia, Canadian Arctic Islands. Geological Society of America Bulletin, 131, pp. 1075-1094. https://doi.org/10.1130/B35017.1

Domeier, M. 2015. A plate tectonic scenario for the Iapetus and Rheic oceans. Gondwana Research, 36, pp. 275-295. https://doi.org/10.1016/j.gr.2015.08.003

Domeier, M. and Torsvik, T.H. 2014. Plate tectonics in the late Paleozoic. Geoscience Frontiers, 5, pp. 303-350. https://doi.org/10.1016/j.gsf.2014.01.002

Dumoulin, J.A., Jones, J.V. III, Bradley, D.B., Till, A.B., Box, S.E., and O'Sullivan, P.B. 2018a. Neoproterozoic-early Paleozoic provenance evolution of sedimentary rocks in and adjacent to the Farewell terrane (interior Alaska). Geosphere, 14 (2), pp. 367-394. https://doi.org/10.1130/ GES01470.1

Dumoulin, J.A., Jones, J.V III., Box, S.E., Bradley, D.B., Ayuso, R.A., and O'Sullivan, P.B. 2018b. The Mystic subterrane (partly) demystified: new data from the Farewell terrane and adjacent rocks, interior Alaska, Geosphere, 14 (4), pp. 1501-1543. https://doi.org/10.1130/GES01588.1

Eberle, J.J. and Greenwood, D.R. 2012. Life at the top of the greenhouse Eocene world-a review of the Eocene flora and vertebrate fauna from Canada's High Arctic. Geological Society of America Bulletin, 124, pp. 3-23. https://doi. org/10.1130/B30571.1

Embry, A.F. 1991. Middle Upper Devonian clastic wedge of the Arctic Islands. In Geology of the Innuitian Orogen and Arctic Platform of Canada and Greenland. Edited by H.P. Trettin. Geological Survey of Canada, Geology of Canada, 3, pp. 261-280. https://doi.org/10.1130/DNAGGNA-E.261

Embry, A.F. 1993. Crockerland - the northwest source area for the Sverdrup Basin. Canadian Arctic Islands. In Arctic geology and petroleum potential. Edited by T.O. Vorren. Norwegian Petroleum Society Special Publication 2, pp. 205-216. https://doi.org/10.1016/B978-0-444-88943$\underline{0.50018-6}$

Embry, A.F. and Beauchamp, B. 2008. Sverdrup Basin. In Sedimentary basins of the world, volume 5: the sedimentary basins of the United States and Canada. Edited by A. Miall. Elsevier, Amsterdam, The Netherlands, pp. 451472. https://doi.org/10.1016/S1874-5997(08)00013-0

Embry, A., Beauchamp, B., Dewing, K., and Dixon, J. 2019. Episodic tectonics in the Phanerozoic succession of the Canadian High Arctic and the "10-million-year flood". In Circum-Arctic structural events: tectonic evolution of the Arctic margins and Trans-Arctic links with adjacent orogens. Edited by K. Piepjohn, J.V. Strauss, L. Reinhardt, L., and W.C. McClelland. Geological Society of America Special Paper 541, pp. 213-230. https://doi. org/10.1130/2018.2541(11)
England, J. 1987. Glaciation and the evolution of the Canadian High Arctic landscape. Geology, 15, pp. 419-424. https://doi.org/10.1130/0091-7613(1987)15<419:GATEOT>2.0.CO;2

Ershova, V.B., Khudoley, A.K., Prokopiev, A.V., Tuchkova, M.I., Fedorov, P.V., Kazakova, G. G., Shishlov, S.B., and O'Sullivan, P. 2016. Trans-Siberian Permian rivers: a key to understanding Arctic sedimentary provenance. Tectonophysics, 691, pp. 220-233. https://doi.org/10.1016/j. tecto.2016.03.028

Fleming, E.J., Flowerdew, M.J., Smyth, H.R., Scott R.A., Morton, A.C., Omma, J.E., Frei, D. and Whitehouse, M.J. 2016. Provenance of Triassic sandstones on the southwest Barents Shelf and the implication for sediment dispersal patterns in northwest Pangaea. Marine and Petroleum Geology, 78, pp. 516-535. https://doi.org/10.1016/j.marpetgeo.2016.10.005

Friend, P.F. and Williams, B.P.J. 2000. New perspectives on the Old Red Sandstone. Geological Society London, Special Publication 180, 400 p. https://doi.org/10.1144/GSL. SP.2000.180.01.04

Gasser, D. 2013. The Caledonides of Greenland, Svalbard and other Arctic areas: status of research and open questions. In New perspectives on the Caledonides of Scandinavia and related areas. Edited by F. Corfu, D. Gasser, and D.M. Chew. Geological Society London, Special Publication 390, pp. 93-129. https://doi.org/10.1144/SP390.17

Geist, E.L., Vallier, T.L., and Scholl, D.W. 1994. Origin, transport, and emplacement of an exotic island-arc terrane exposed in eastern Kamchatka, Russia. Geological Society of America Bulletin, 106, pp. 1182-1194. https:// doi.org/10.1130/0016-7606(1994)106<1182:OTAEOA >2.3.CO; 2

Gottlieb, E.S., Meisling, K.E., Miller, E.L., and Charles, G. 2014. Closing the Canada Basin: detrital zircon geochronology relationships between the North Slope of Arctic Alaska and the Franklinian mobile belt of Arctic Canada. Geosphere, 10, pp. 1366-1384. https://doi.org/10.1130/ GES01027.1

Gradstein, F.M, Ogg, J.G., Schmitz, M.D., Ogg, G.M., Agterberg, F.P., Aretz, M., Becker, T.R., Butcher, A., Ernst, R.E., Esmeray-Senlet, S., Fensome, R.A., Gale, A.S., Gréselle, B., Gibbard, P.L., Goldman, D., Grossman, E.L., Halverson, G.P., Henderson, C.M., Hesselbo, S.P., et al. in press. The Geologic Time Scale 2020. Elsevier, Amsterdam, 2 volumes, ca. $1300 \mathrm{p}$.

Grantz, A., Clark, D.L., Phillips, R.L., and Srivastava, S.P. 1993. Phanerozoic stratigraphy of Northwind Ridge, magnetic anomalies in the Canada Basin, and the geometry and timing in the Amerasia basin, Arctic Ocea. Geological Society of America Bulletin, 110, pp. 801-820. https://doi.org/10.1130/0016-7606(1998)110<0801:PSONRM $>2.3 . \mathrm{CO} ; 2$

Harrison, J.C., Mayr, U., McNeil, D.H., Sweet, A.R., McIntyre, D.J., Eberle, J.J., Harington, C.R., Chalmers, J.A., Dam, G., and Nøhr-Hansen, H. 1999. Correlation of Cenozoic sequences of the Canadian Arctic region and Greenland; 
implications for the tectonic history of northern North America. Bulletin of Canadian Petroleum Geology, 47, pp. 223-254.

Houseknecht, D.W., Bird, K.J., and Schenk, C.J. 2009. Seismic analysis of clinoform depositional sequences and shelf-margin trajectories in Lower Cretaceous (Albian) strata, Alaska North Slope. Basin Research, 21, pp. 644654. https://doi.org/10.1111/j.1365-2117.2008.00392.x

Israel, S., Beranek, L.P., Friedman, R.M., and Crowley, J.L. 2014. New ties between the Alexander terrane and Wrangellia and implications for North America Cordilleran evolution. Lithosphere, 6, pp. 270-276. https://doi. org/10.1130/L364.1

Jicha, B.R., Scholl, D.W., Singer, B.S., Yogodzonski, G. M., and Kay, S. M. 2006. Revised age of Aleutian Island Arc formation implies high rate of magma production. Geology, 34, pp. 661-664. https://doi.org/10.1130/G22433.1

Klausen, T.G., Nyberg, B., and Helland-Hansen, W. 2019. The largest delta plain in Earth's history. Geology, 47, pp. 470-474. https://doi.org/10.1130/G45507.1

Kontorovich, A.E., Kontorovich, V.A., Ryzhkova, S.V., Shurygin, B.N., Vakulenko, L.G., Gaideburova E.A., Danilova, V.P., Kazanenkov, V.A, Kim, N.S., Kostyreva, E.A., Moskvin, V.I., and Yan, P.A. 2013. Jurassic paleogeography of the West Siberian sedimentary basin. Russian Geology and Geophysics, 54, pp. 747-779. https://doi. org/10.1016/j.rgg.2013.07.002

Kuznetsov, N.B., Natapov, L.M., Belousova, E.A., Griffin, U.L., O'Reilly, S. 2010. Geochronological, geochemical and isotopic study of detrital zircon suites from late Neoproterozoic clastic strata along the NE margin of the East European Craton: implications for plate tectonic models. Gondwana Research, 17 (2-3), pp. 583-601. https://doi. org/10.1016/j.gr.2009.08.005

Lane, L.S. 1997. Canada Basin, Arctic Ocean: evidence against a rotational origin. Tectonics, 16, pp. 363-387. https://doi.org/10.1029/97TC00432

Lane, L.S. 2007. Devonian-Carboniferous paleogeography and orogenesis, northern Yukon and adjacent Arctic Alaska. Canadian Journal of Earth Sciences, 44, pp. 679694. https://doi.org/10.1139/e06-131

Larsen, P.H. and Bengaard, H.J. 1991. Devonian basin initiation in East Greenland: a result of sinistral wrench faulting and Caledonian extensional collapse. Journal of the Geological Society of London, 148, pp. 355-368. https:// doi.org/10.1144/gsigs. 148.2.0355

Lawver, L.A. and Scotese, C.R. 1990. A review of tectonic models for the evolution of the Canada Basin. Geological Society of America, The geology of North America, L, pp. 593-618. https://doi.org/10.1130/DNAG-GNA-L.593

Malkowski, M.A. and Hampton, B.A. 2014. Sedimentology, $\mathrm{U}-\mathrm{Pb}$ detrital geochronology, and $\mathrm{Hf}$ isotopic analyses from Mississippian-Permian stratigraphy of the Mystic subterrane, Farewell terrane, Alaska. Lithosphere, 6 (5), pp. 383-398. https://doi.org/10.1130/L365.1

Manuszak, J.D., Ridgway, K.D., Trop, J.M., and Gehrels, G.E. 2007. Sedimentary record of the tectonic growth of a collisional continental margin: Upper Jurassic - Lower Cretaceous Nutzotin Mountains sequence, eastern Alaska Range, Alaska. In Tectonic Growth of a Collisional Continental Margin: Crustal Evolution of Southern Alaska. Edited by K.D. Ridgway, J.M. Trop, J.M.G. Glen, and O’Neill, J.M. Geological Society of America Special Paper 431, pp. 345-377. https://doi.org/10.1130/2007.2431(14)

McKerrow, W.S., Mac Niocaill, C., and Dewey, J.F. 2000. The Caledonian Orogeny redefined. Journal of the Geological Society of London, 157, pp. 1149-1154. https://doi. org/10.1144/jgs.157.6.1149

Metelkin, D.V., Vernikovsky, V.A., Matushkina, N.Y. 2015. Arctida between Rodinia and Pangea. Precambrian Research, 259, pp. 114-129. https://doi.org/10.1016/j.precamres.2014.09.013

Mihalynuk, M.G., Nelson, J., and Diakow, L.J. 1994. Cache Creek terrane entrapment: oroclinal paradox within the Canadian Cordillera. Tectonics, 13, pp. 575-595. https:// doi.org/10.1029/93TC03492

Miller, E.L., Gehrels, G.E., Pease, V., and Sokolov, S. 2010. Stratigraphy and $\mathrm{U}-\mathrm{Pb}$ detrital zircon geochronology of Wrangel Island, Russia: implications for Arctic paleogeography. American Association of Petroleum Geologists Bulletin, 94 (5), pp. 665-692. https://doi. org/10.1306/10200909036

Miller, E., Kuznetsov, N., Soboleva, A., Udoratina, O., Grove, M., and Gehrels, G. 2011. Baltica in the Cordillera? Geology, 39, pp. 791-794. https://doi.org/10.1130/G31910.1 Miller, E.L., Meisling, K. E., Akinin, V.V., Brumley, K., Coakley, B.J., Gottlieb, E.S., Hoiland, C.W., O’Brien, T.M., Soboleva, A., and Toro, J. 2017. Circum-Arctic Lithosphere Evolution (CALE) Transect C: displacement of the Arctic Alaska-Chukotka microplate towards the Pacific during opening of the Amerasia Basin of the Arctic. In Circum-Arctic lithosphere evolution. Edited by V. Pease and B. Coakley. Geological Society of London, Special Publication, 460. https://doi.org/10.1144/SP460.9

Monger, J.W.H. 2008. Evolution of Canada's western mountains. Geological Survey of Canada, Open File 5804 (poster). https://doi.org/10.4095/225581

Monger, J.W.H. and Nokleberg, W.J. 1996. Evolution of the northern North American Cordillera; generation, fragmentation, displacement, and accretion of successive North American plate margin arcs. In Geology and ore deposits of the American Cordillera. Edited by A.R. Coyner and P.L. Fahey. Geological Society of Nevada Symposium, Reno/Sparks, Nevada, 1995, Proceedings, pp. 1133-1152.

Moore, T.E., Dumitru, T.A., Adams, K.E., Witebsky, S.N., and Harris, A.G. 2002. Origin of the Lisburne Hills - Herald Arch structural belt: stratigraphic, structural, and fission-track evidence from the Cape Lisburne area, northwestern Alaska. In Tectonic evolution of the Bering Shelf Chukchi Sea - Arctic margin and adjacent landmasses. Edited by E.L. Miller, A. Grantz, and S.L. Klemperer. Geological Society of America Special Paper 360, pp. 77-109. https://doi.org/10.1130/0-8137-2360-4.77 
Nelson, J.L., Colpron, M., and Israel, S. 2013. The Cordillera of British Columbia, Yukon, and Alaska: tectonics and metallogeny. In Tectonics, metallogeny, and discovery: the North American Cordillera and similar accretionary settings. Edited by M. Colpron, T. Bissing, B.G. Rusk, and J.F.H. Thompson. Society of Economic Geologists, Special Publication 17, pp. 53-109. https://doi.org/10.5382/ SP.17.03

Nelson, L.L., Strauss, J.V., Crockford, P.W., Cox, G.M., Johnson, B.G., Ward, W.P., Colpron, M., McClelland, W.C., and Macdonald, F.A. 2018. Nd isotopic and geochemical constraints on the provenance of pre-Mississippian sedimentary rocks in the North Slope of Yukon and Alaska. In Circum-Arctic structural events: tectonic evolution of the Arctic margins and trans-Arctic links with adjacent orogens. Edited by K. Piepjohn, J.V. Strauss, L. Reinhart, and E.C. McClelland. Geological Society of America Special Paper 541, pp. 573-592. https://doi. org/10.1130/2018.2541(24)

Nikishin, A.M., Ziegler, P.A., Stephenson, R.A., Cloetingh, S.A.P.L., Furne, A.V., Fokin, P.A., Ershov, A.V., Bolotov, S.N., Korotaev, M.V., Alekseev, A.S., and Gorbachev, V.I. 1996. Late Precambrian to Triassic history of the East European Craton: dynamics of sedimentary basin evolution. Tectonophysics, 268 (1), pp. 23-63. https://doi. org/10.1016/S0040-1951(96)00228-4

Nilsen, T.H. 1981. Upper Devonian and Lower Mississippian redbeds, Brooks Range, Alaska; In. Sedimentation and tectonics in alluvial basins. Geological Association of Canada Special Paper 23, pp.187-219.

Nilsen, T.H. and Moore, T.E. 1984. Stratigraphic nomenclature for the Upper Devonian and Lower Mississippian(?) Kanayut conglomerate, Brooks Range, Alaska. United States Geological Survey Bulletin 1529-A, pp. A1-A64.

Nokleberg, W.J., Parfenov, L.M., Monger, J.W., Norton, I.O., Chanduk, A.I., Stone, D.B., Scotese, C.R., Scholl, D.W., and Fujita, K. 2000. Phanerozoic tectonic evolution of the circum-North Pacific. United States Geological Survey Professional Paper 1626, 122 p. https://doi.org/10.3133/ pp1626

Parfenov, L. M.,1997. Geological structure and geological history of Yakutia. In Geological monuments of the Sakha Republic (Yakutia). Edited by L.M Parfenov and V.B. Spektor. Novosibirsk, Studio Design, pp. 60-77.

Parfenov, L.M., Prokopiev, A.V., and Gaiduk, V.V. 1995. Cretaceous frontal thrusts of the Verkhoyansk fold belt, eastern Siberia. Tectonics, 14 (2), pp. 342-358. https://doi. org/10.1029/94TC03088

Pease, V., Drachev, S., Stephenson, R., and Zhang, X. 2014. Arctic lithosphere - a review; Tectonophysics, 628, p. 1-25. https://doi.org/10.1016/j.tecto.2014.05.033

Petrov, O.V. and Pubellier, M. (editors) 2018. Tectonic map of the Arctic. http://www.vsegei.com/en/intcooperation/ temar-5000. https://doi.org/10.14683/2018TEMAR10M

Petrov, O.V., Sobolev, N.N., Koren, T., Vasiliev, V.E., Petrov, E.O., Larssen, G.B., and Smelror, M. 2008. Palaeozoic and early Mesozoic evolution of the East Barents and Kara
Seas sedimentary basins. Norwegian Journal of Geology, 88, pp. 227-234.

Petrov, O.V., Morozov, M., Shokalsky, S., Kashubin, S., Artemieva, I.M., Sobolev, N., Petrov, E., Ernst, R.E., Sergeey, S., and Smelror, M. 2016. Crustal structure and tectonic model of the Arctic region. Earth-Science Reviews, 154, pp. 29-71. https://doi.org/10.1016/j.earscirev.2015.11.013

Rowley, D.B. and Lottes, A.L. 1988. Plate-kinematic reconstructions of the North Atlantic and Arctic: Late Jurassic to present. Tectonophysics, 155, pp. 73-120. https://doi. org/10.1016/0040-1951(88)90261-2

Ryan, W.B.F., Carbotte, S.M., Coplan, J.O., O’Hara, S., Melkonian, A., Arko, R., Weissel, R.A., Ferrini, V., Goodwillie, A., Nitsche, F., Bonczkowski, J., and Zemsky, R. 2009. Global multi-resolution topography synthesis. Geochemistry Geophysics Geosystems, 10, pp. 1-9. https://doi. org/10.1029/2008GC002332

Sample, J.C. and Reid, M.R. 2003. Large-scale, latest Cretaceous uplift along the northeast Pacific Rim: evidence from sediment volume, sandstone petrography, and $\mathrm{Nd}$ isotope signatures of the Kodiak Formation, Kodiak islands, Alaska. In Geology of a transpressional orogen developed during ridge-trench interaction along the North Pacific margin. Edited by V.B Sisson, S.M. Roeske and T.L. Pavlis. Geological Society of America Special Paper 371, pp. 1-20. https://doi.org/10.1130/0-8137-2371-X.51

Sauermilch, I., Weigelt, E., and Jokat, W. 2018, Pre-rift sedimentation of the Lomonosov Ridge, Arctic Ocean at $84^{\circ} \mathrm{N}$-a correlation to the complex geologic evolution of the conjugated Kara Sea. Journal of Geodynamics, 118, pp. 49-54. https://doi.org/10.1016/j.jog.2018.05.002

Sears, J.W. 2013. Late Oligocene-Early Miocene Grand Canyon: a Canadian connection? GSA Today, 23, pp. 4-10. https://doi.org/10.1130/GSATG178A.1

Seton, M., Müler, R.D., Zahirovic, S., Gaina, C., Torsvik, T.H., Shephard, G., Talsma, A., Gurnis, M., Turner, M., and Maus, S. 2012. Global continental and ocean basin reconstructions since $200 \mathrm{Ma}$, Earth-Science Reviews, 113, pp. 212-270. https://doi.org/10.1016/j.earscirev.2012.03.002

Shephard, G.E., Muiller, D., and Seton, M. 2013. The tectonic evolution of the Arctic since Pangea breakup: integrating constraints from surface geology and geophysics with mantle structure. Earth-Science Reviews, 124, pp. 148183. https://doi.org/10.1016/j.earscirev.2013.05.012

Sherwood, K.W., Johnston, P.P., Craig, J.D., Zerwick, S.A., Lothamer, R.T., Thurston, D.K., and Hurlbert, S.B. 2002. Structure and stratigraphy of the Hanna Trough, U.S. Chukchi Shelf, Alaska. In Tectonic evolution of the Bering Shelf - Chukchi Sea - Arctic margin and adjacent landmasses. Edited by E.L. Miller, A. Grantz, and S.L. Klemperer. Geological Society of America Special Paper 360, pp. 39-66. https://doi.org/10.1130/0-8137-2360-4.39

Sibuet, J, Rouzo, S., and Srivastava, S. 2012. Plate tectonic reconstructions and paleogeographic maps of the central and North Atlantic oceans. Canadian Journal of Earth Sciences, 49, pp. 395-415. 
Smelror, M. and Petrov, O.V. 2018. Geodynamics of the Arctic: from Proterozoic orogens to present day seafloor spreading. Journal of Geodynamics, 121, pp. 185-204. https://doi.org/10.1016/j.jog.2018.09.006

Smelror, M., Petrov, O., Larssen, G.B., and Werner, S.C. (editors) 2009. Geological history of the Barents Sea: atlas. Geological Survey of Norway, Trondheim, $135 \mathrm{p}$.

Soja, C.M. and White, B. 2016. Lacustrine deposits in the Karheen Formation fortify links between Alaska's Alexander terrane and the Old Red Sandstone continent in the Late Silurian - Early Devonian. Journal of Sedimentary Research, 86, pp. 564-586. https://doi.org/10.2110/ jsr.2016.37

Strauss, J.V., Macdonald, F.A., Taylor, J.F., Repetski, J.E., and McClelland, W.C. 2013. Laurentian origin for the North Slope of Alaska: implications for the tectonic evolution of the Arctic. Lithosphere, 5, pp. 477-482. https://doi. org/10.1130/L284.1

Strauss, J.V., Macdonald, F.A., and McClelland, W.C. 2018a. Pre-Mississippian stratigraphy and provenance of the North Slope of Arctic Alaska I: platformal carbonate rocks of the northeastern Brooks Range and their significance in circum-Arctic evolution. In Circum-Arctic structural events: tectonic evolution of the Arctic margins and trans-Arctic links with adjacent orogens. Edited by K. Piepjohn, J.V. Strauss, L. Reinhart, and W.C. McClelland. Geological Society of America Special Paper 541, pp. 493-524. https://doi.org/10.1130/2018.2541(22)

Strauss, J.V., Johnson, B.G., Colpron, M., Nelson, L.L., Perez, J.L., Benowitz, J.A., Ward, W.P., and McClelland, W.C. 2018b. Pre-Mississippian stratigraphy and provenance of the North Slope of Arctic Alaska II: basinal rocks of the northeastern Brooks Range and their significance in circum-Arctic evolution. In Circum-Arctic structural events: tectonic evolution of the Arctic margins and trans-Arctic links with adjacent orogens. Edited by K. Piepjohn, J.V. Strauss, L. Reinhart, and W.C. McClelland. Geological Society of America Special Paper 541, pp. 525-572. https://doi.org/10.1130/2018.2541(23)

Till, A.B. 2016. A synthesis of Jurassic and Early Cretaceous crustal evolution along the southern margin of the Arctic Alaska - Chukotka microplate and implications for defining tectonic boundaries active during opening of Arctic Ocean basins. Lithosphere, 8, pp. 219-237. https://doi. org/10.1130/L471.1

Torsvik, T.H. and Cocks, L.R.M. 2017. Earth history and paleogeography. Cambridge University Press, Cambridge, UK., 317 p.

Trettin, H.P. 1987, Pearya: a composite terrane with Cale- donian affinities in northern Ellesmere Island. Canadian Journal of Earth Sciences, 24 (2), pp. 224-245. https://doi. org/10.1139/e87-025

Trettin, H.P., Mayr, U., Long, G.D.F., and Packard, J.J. 1991. Chapter 8. Cambrian to Early Devonian basin development, sedimentation, and volcanism, Arctic Islands. In The geology of the Innuitian Orogen and Arctic Platform of Canada and Greenland. Edited by H.P. Trettin. Geological Survey of Canada, Geology of Canada, 3, pp. 165-239. https://doi.org/10.4095/133959 (Also Geological Society of America, Geology of North America, v. E, Boulder, Colorado. https://doi.org/10.1130/DNAG-GNA-E.295

Trop, J.M. and Ridgway, K.D. 2007. Mesozoic and Cenozoic tectonic growth of southern Alaska: a sedimentary basin perspective. In Tectonic growth of a collisional continental margin: crustal evolution of southern Alaska. Edited by K.D. Ridgway, J.M. Trop, J.M.G. Gen and J.M. O’Neill. Geological Society of America, Special Paper 431, pp. 55-94. https://doi.org/10.1130/2007.2431(04)

Umhoefer, P.J. and Blakey, R.C. 2006. Moderate $(1600 \mathrm{~km})$ northward translation of Baja British Columbia from southern California: an attempt at reconciliation of paleomagnetism and geology. In Paleogeography of the North American Cordillera: evidence for and against large-scale displacements. Edited by J.W. Haggart, R.J. Enkin, and J.W.H. Monger. Geological Association of Canada Special Paper 46, pp. 305-327.

Vernikovsky, V.A. and Dobretsov, N.L. 2015. Geodynamic evolution of the Arctic Ocean and modern problems in geological studies of the Arctic region. Herald of the Russian Academy of Sciences, 85, pp. 206-212. https://doi. org/10.1134/S1019331615030193

Vernikovsky, V.A., Dobretsov, N.L., Metelkin, D.V., Matushkin, N.Y., and Koulakov, I.Y. 2013. Concerning tectonics and the tectonic evolution of the Arctic. Russian Geology and Geophysics, 54, pp. 838-858. https://doi. org/10.1016/j.rgg.2013.07.006

Wyld, S.J., Umhoefer, P.J. and Wright, J.E. 2006. Reconstructing northern Cordilleran terranes along known Cretaceous and Cenozoic strike-slip faults: implications for the Baja British Columbia hypothesis and other models. In Paleogeography of western North America: evidence for and against large-scale displacements. Edited by J.W. Haggart, R.J. Enkin, and J.W.H. Monger. Geological Association of Canada Special Paper 46, pp.277-298.

Ziegler, P.A. 1988. Evolution of the Arctic-North Atlantic and the western Tethys. American Association of Petroleum Geologists Memoir 43, 198 p.

Editorial responsibility: Robert A. Fensome 